\title{
ظلال المعاني في دعاء كميل
}

م. د. قاسم صاحب كريم الأسدي

الجامعة المستنصرية / كلية العلوم السياسية

Mon20600@gmail.com

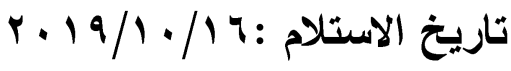

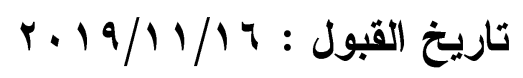

(c) (i)

This work is licensed under a Creative Commons Attribution 4.0 International License

الملخص :

سعت هذه الدراسة إلى معرفة ظلال المعاني في بعض ألفاظ النص ومبانبه المختارة

وتز اكيها، ليتسنى للباحث الغوص في أعماق النص، و استخراج خصائصد، ومكنونه اللغوي ،

و إماطة اللثام عما تضمره ألفاظه ومبانيه، ومشاهدة صوره التي رسمت بوساطة تلك الظلله. وقد اعتمدت الانتقاء في هذه الدر اسة؛ لأنّ الألفاظ لا تمتلك جميعها ظلالاً ، بل هناك ألفاظ

خاصة، وثر اكيب مختارة. تألف البحث من فصلين: درست في الفصل الأول المهاد التظظيري، فبينت فىه المدلول اللغوي والاصطلاحي لمفهوم الظلال، فضلاً عمّا بيّتُه من المصطلحات الات المماثلة أو المرادفة، أو المقابلة له أيضاً، القديم منها و الحديث، ليتسنى لي معرفة المفهوم المقصود والاحاطة به، وخصصت الفصل الثاني للار اسة التطبيقية، ومن ثم ختمت البحث بخاتمة ذكرت فيها أبرز ما توصلت إليه من نتائج. أما المنهج الذي اعتمدته فهو المنهج الوصفي التحليلي

الكلمات المفتاحيّة: ظل المعاني، دعاء كميل ، المنهج الوصفي التحليلي 


\title{
Shades of Meaning in Kumail's Du'aa Instructor:Qassem Sahib Karim Al' Assadi (Ph.D.) College of Political Sciences / Al- Mustansiriya University
}

Mon20600@gmail.com

\begin{abstract}
This study aims to identify the shades of meanings of some words and the structures of the selected text constructions, so that the researcher can dive into the depths of the text, and extract the characteristics, and linguistic potential, and to uncover what damages the word and constructions, and watch the pictures painted by those shades

The research is based on selections in this study because the vocabulary does not have all shades, but there are words in particular, and compositions selected, as the research consists of two sections: the first section sheds lights on the theoretical background where linguistic and idiomatic meaning of the concept of shades have been presented, including synonymous terms, or antonyms. Section two deals with the practical part of the study. The researcher has adopted descriptive analytical approach to achieve the aims of the study. The study ends with relevant conclusion and references.
\end{abstract}

Keywords: shades meaning, Kumail's Du'aa, descriptive analytical approach 
الدعاء الذي بين أيدينا، من الأدعية المعروفة، وهو دعاء الخضر (عليه السلام) وقد علّمه أمير المؤمنين (عليه السلام) كميلا، وهو من خواصن أصحابه، وقد انماز الدعاء الدهاء باختبار الألفاظ

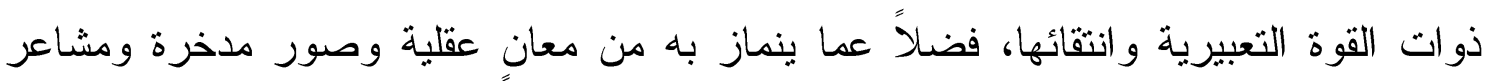
كامنة.

تكون البحث من فصلين، وخاتمة، ومسرد بمصادر البحث ومر اجعه: درست في الفصل الأول المهاد التنظيري، فبينت فيه المفهوم اللغوي و الاصطلاحي، لظاهرة ظلال المعاني، وكذلك

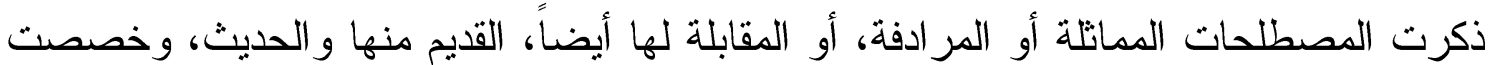

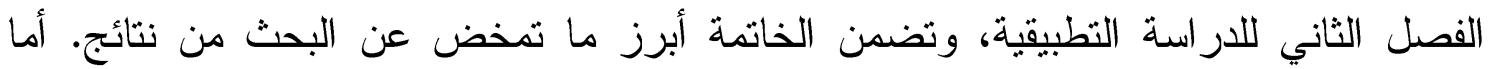

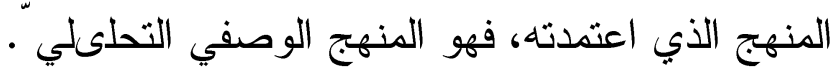

التمهيد:

مما لا ريب فيه أن في النص رموزاً تدل على مضامين، يبتغيها المنشئ، أو الكاتب، ولكل منها معنى معجمي، ومعان أخر، منها: النحوي والصرفي والحرفي والمجازي و السياقي و الدلالي...، وبعضها، قد لا يمكن الوصول إليها إلا بإعمال الفكر، وهي بطبيعة الحال تختلف

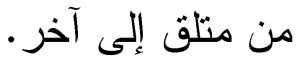

ومن المعلوم أن المعنى المعجمي، هو: الذي نَسنقيه من المعجمات المختلفة ، ويُمتّل المعنى الأصلي للفظ الذي تواضعت عليه العرب، الذي سُمّيَ المعنى المركزي(أنبس، 19 19 ا،

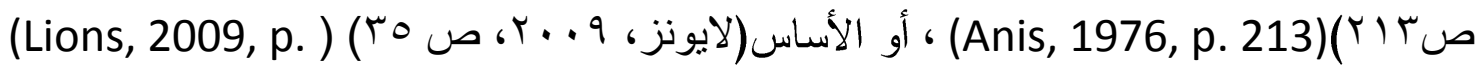

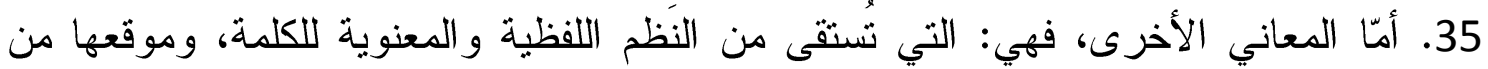

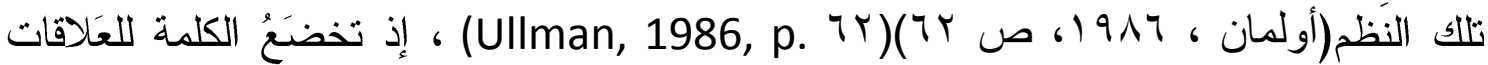

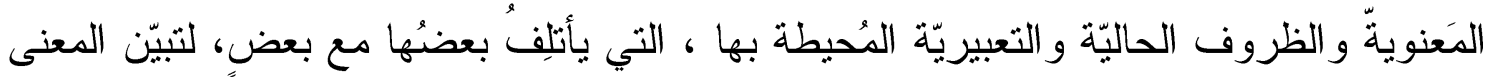

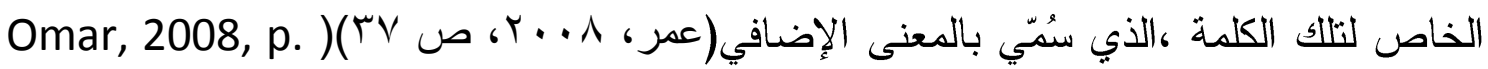

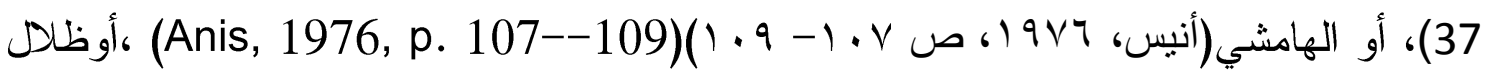

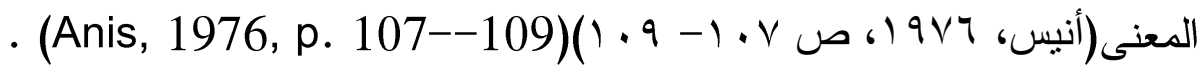




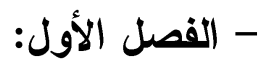

- مفهوم الظل لغةً و واصطلاحًا:

قبل البدء بالتعريف اللغوي لهذا اللفظ، يجب أن نتعرف المصطلحات المماتلة أو المرادفة،

$$
\text { أو المقابلة له أيضاً، القديم منها و الحديث. }
$$

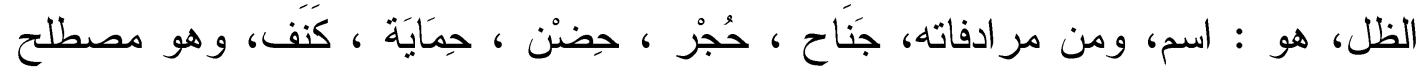

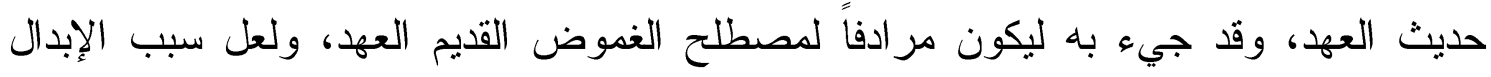

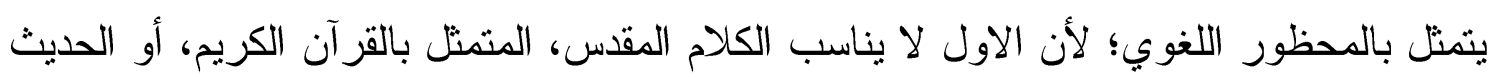

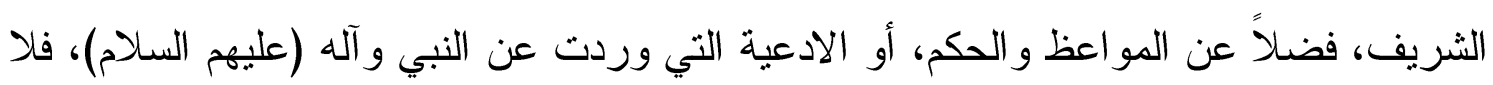
يمكن للباحث أو المفسر أن يقول في القرآن الكريم غموضاً، ولكن يمكن أن يقول فيه أو لهادئ ظلاً

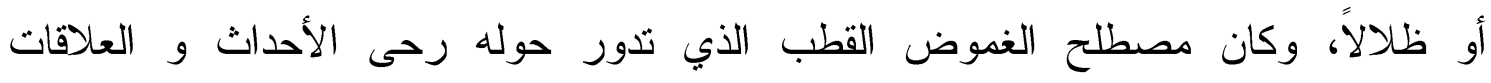

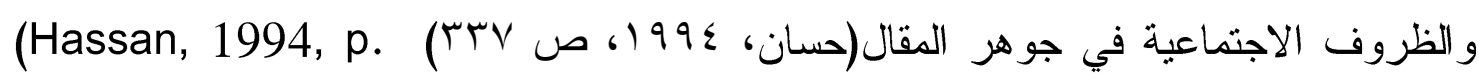

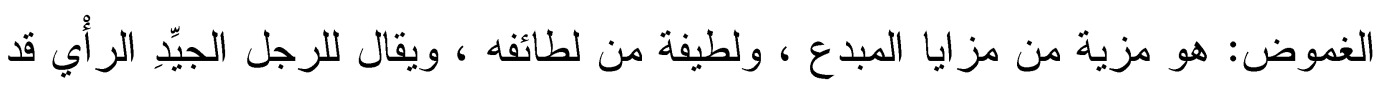

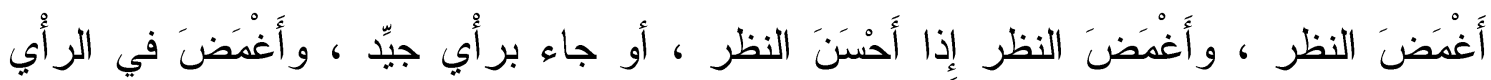

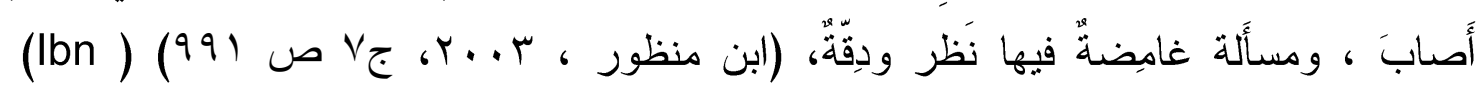
.Manzoor, 2003, Vol. 7 p 991

و"حدد وليام إمبسون أنماط الغموض في سبعة أنواع: ثلاثة منها تتصل بالنص، وثلاثة

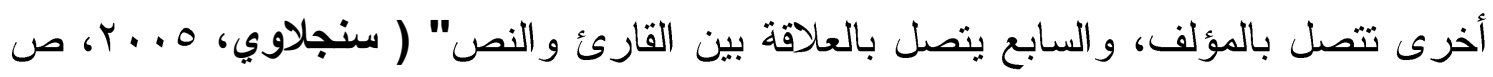

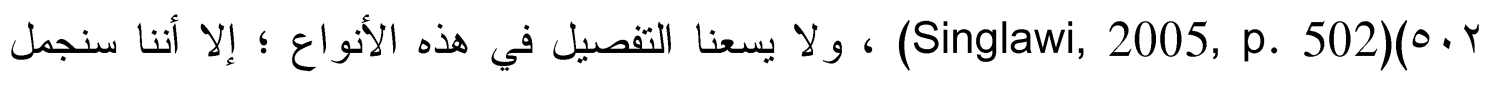

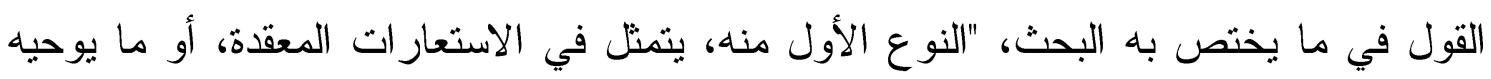

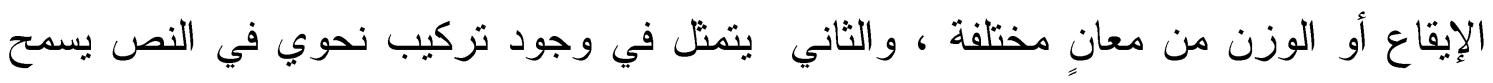
بتعدد التأويلات. و الثالث يقع حين يسمح النص بفهم معنيين مختلفين في آن واحد، ويتمثل في وني

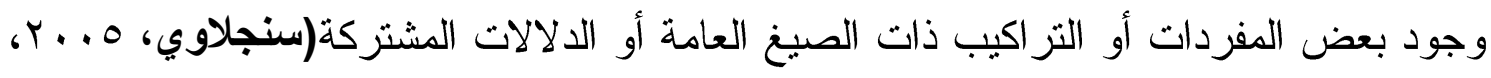

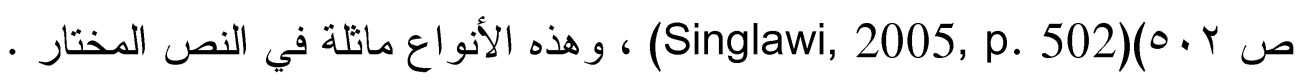

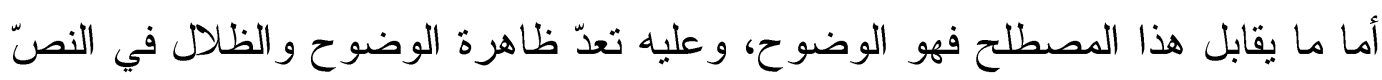
القرآني التي عبّر المفسرون عن جزء منها بالمحكم والمتشابه إحدى سمات النصّّ التي تبيّن

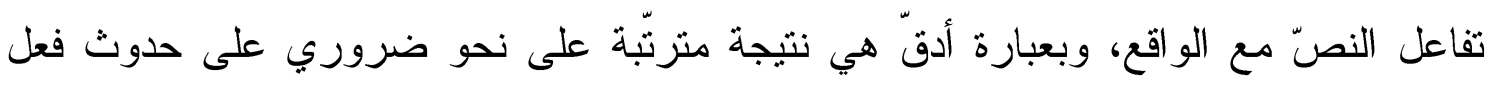


القر اءة والتلقي، فحكم الوضوح أو الخفاء ناتج عن جدلٍ في الو اقع بين شيء مفهوم بدقّة وآخر

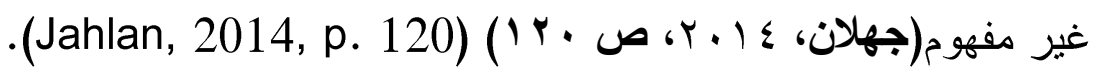

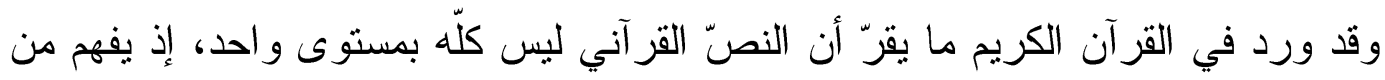

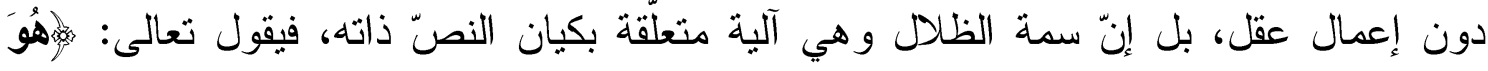

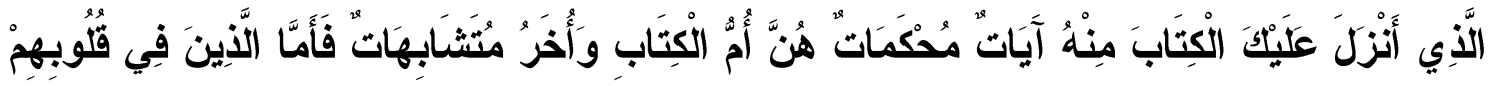

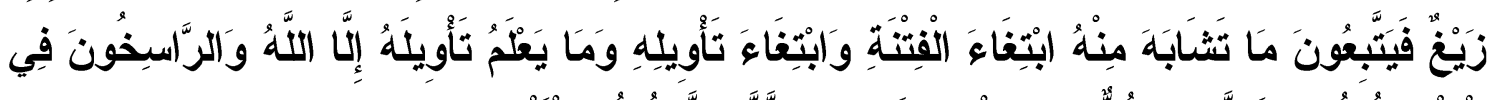

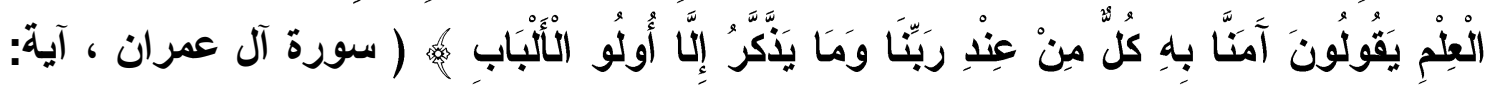

الظلّ لغةً:

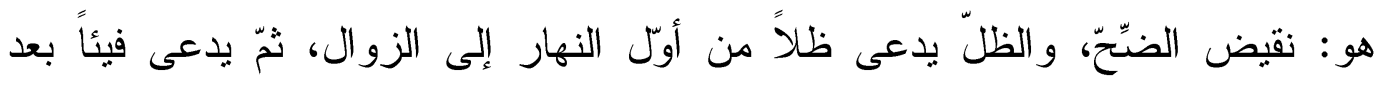

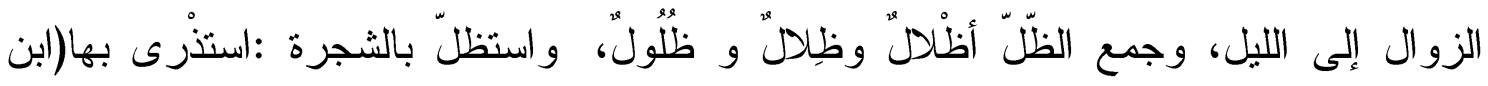

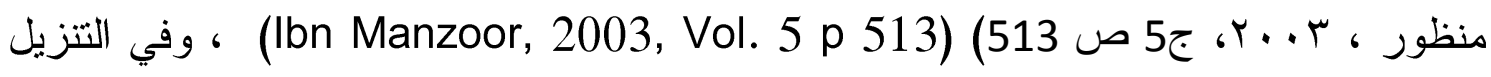

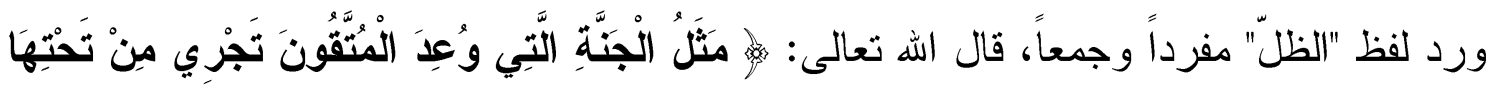

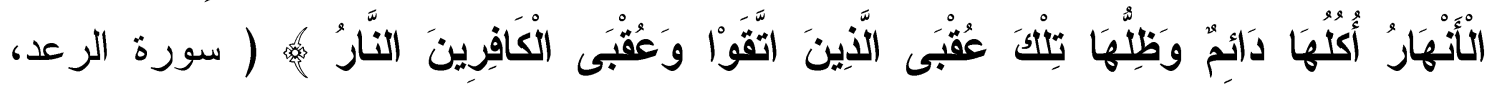

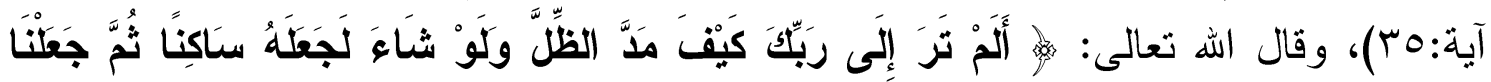

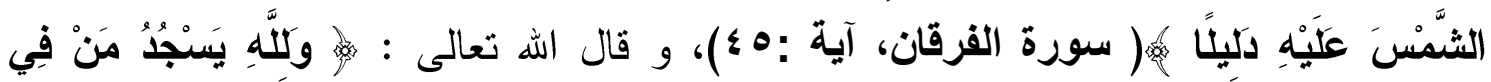

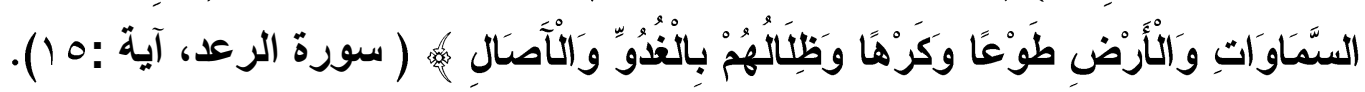

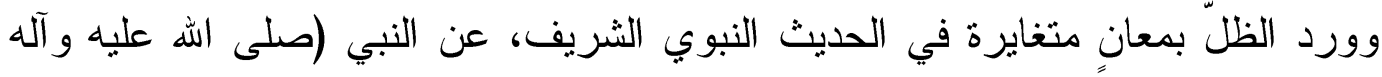

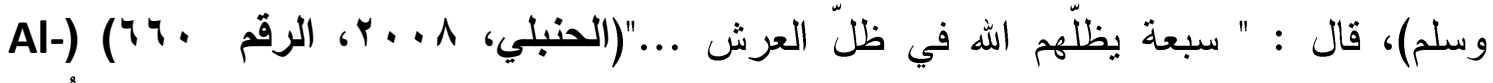

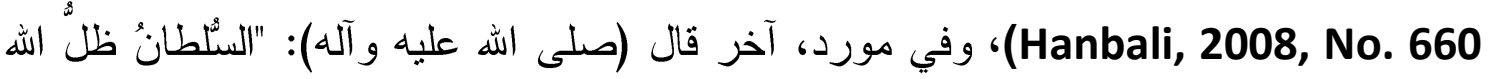

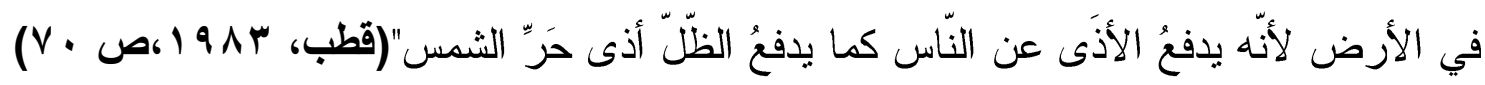

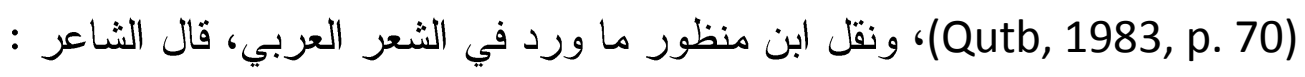

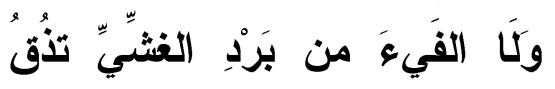

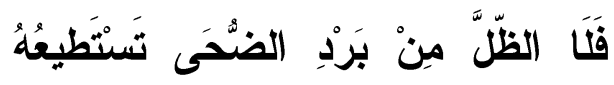

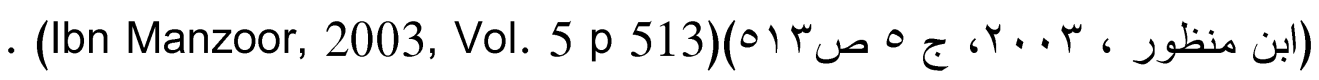

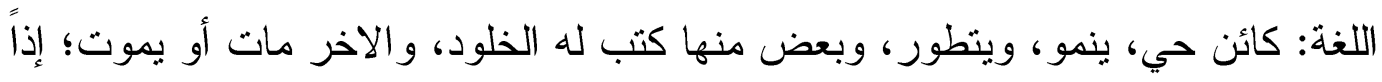

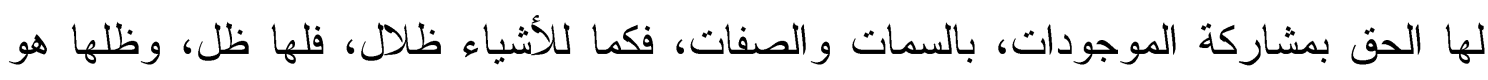

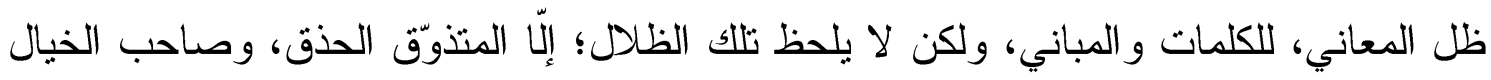

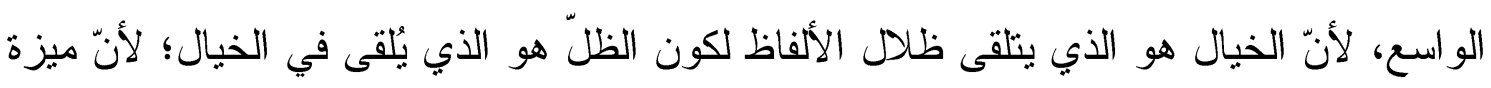


التعبير الأدبي الراقي :"هي الظلاد التي يخلعها وراء المعاني، والإيقاع الذي يتّق مع هذه

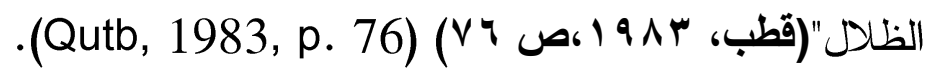

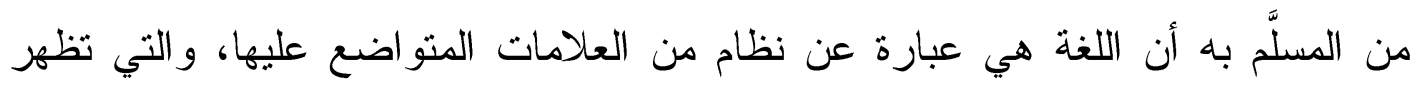
بوساطتها التز اكيب اللغوية، و التي بها تستبان ظلاد الألفاظ، فتضمن من خلادها البهاء البقاء الأبدي ،

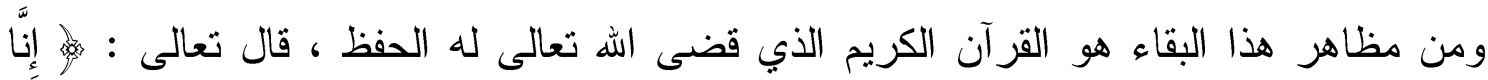

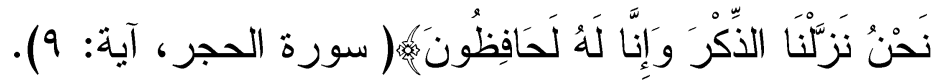

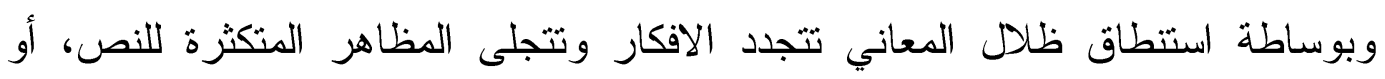

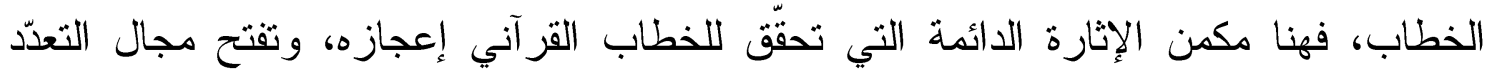

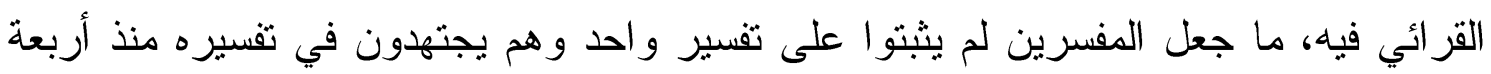

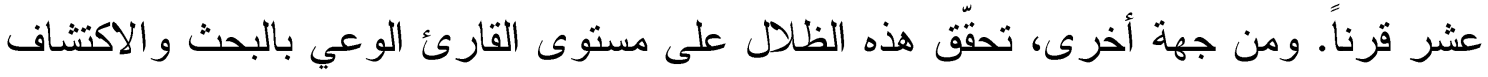

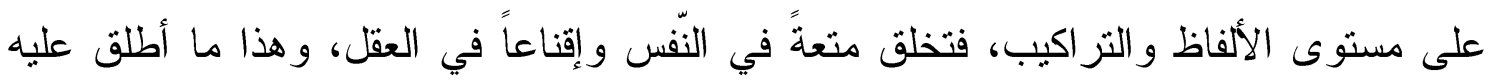

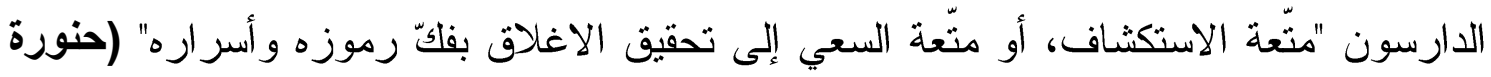

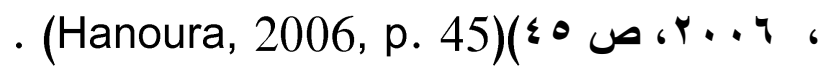

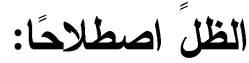

هو "خرق قوانين السمات الدلالية، فخرج الاستعمال من معناه الأساسي(المعجمي) إلى الى

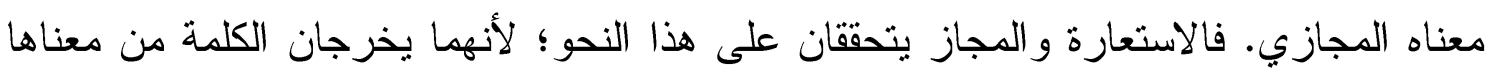

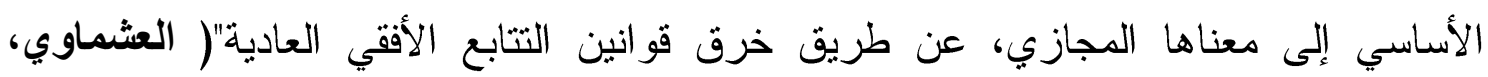

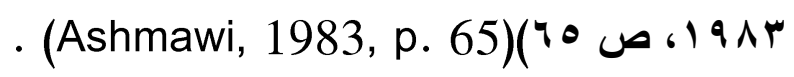
قال وليم رآيت: " تتطوي الآلية الحقيقية للقر اءة على الكثف في ( داخل) كل وحدة من

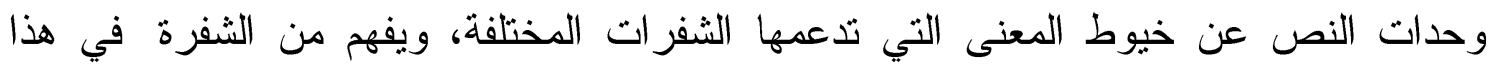

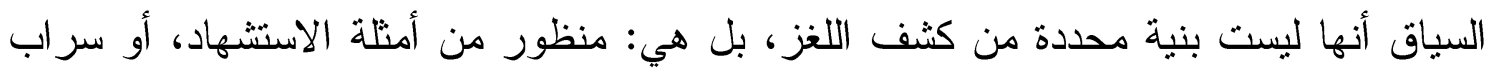

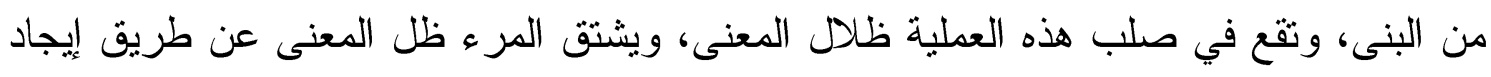

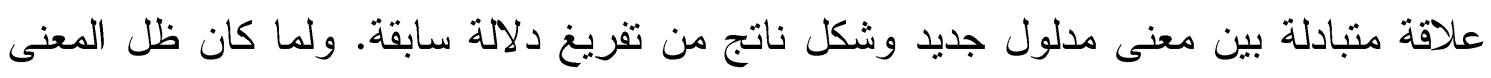

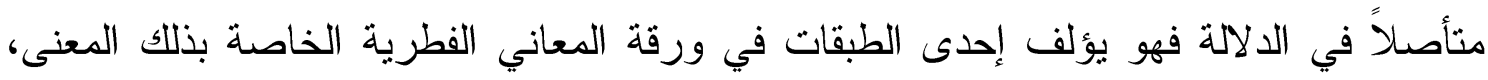

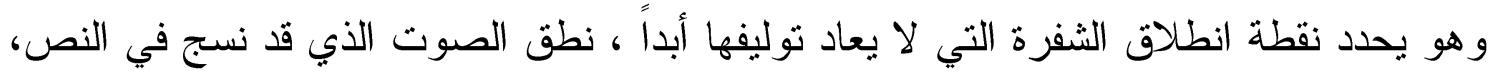
ومع ذلك فإن ظل المعنى ليس مجرد وظيفة نعاقب النص الذي ينطوي على على المعنى الأولي.

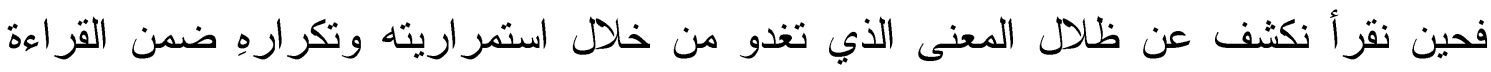




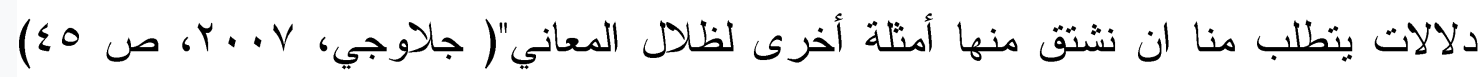
.(Glaughey, 2007, p. 45) ولذلك لا تتحدد معاني الكلمات وقيمها بوساطة المعجم اللغوي المتجرد عن المعاني

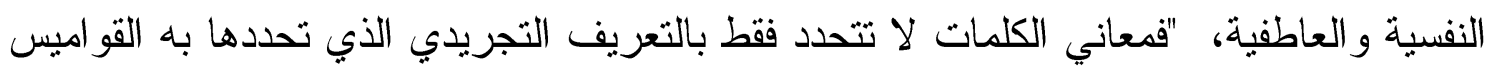

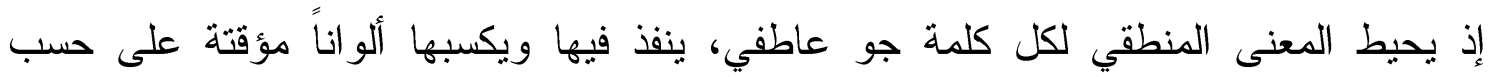

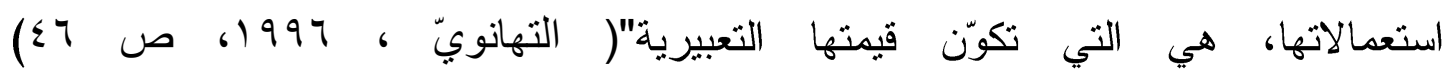
(Congratulations, 1996, p. 46). نلحظ مما تقدم أنّ النّص أو الخطاب بتضمّن جملة من الكلمات و التراكيب، تتعاقب تلاك الالفاظ و المباني بين الوضوح و الغوض، ويمكن ايضاح الغموض بالإيضاح ، أو بنفسه؛ لأنه النه

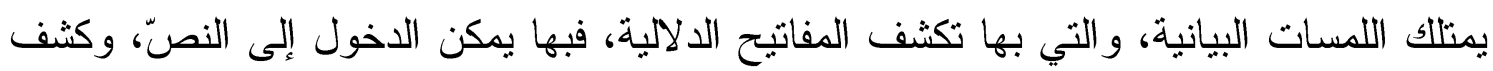

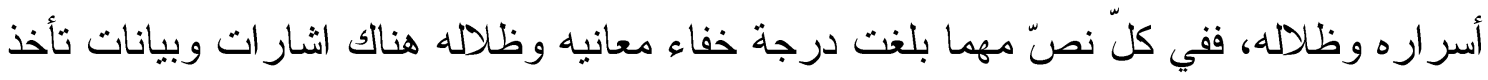
القارئ لفهم الجو انب المستخرة منه و اكتشافها.

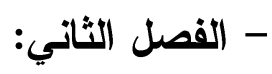

بعد هذا العرض المقتضب، لمفهوم الظلال، نشرع _بحول الله وقوته، بإظهار ظلال

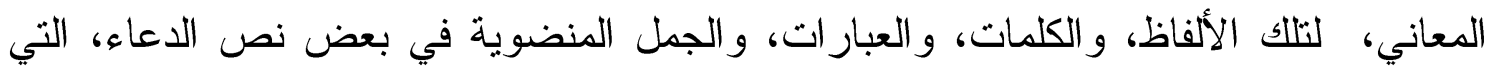

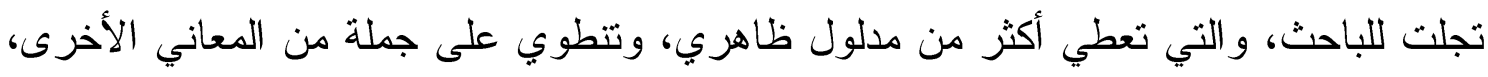

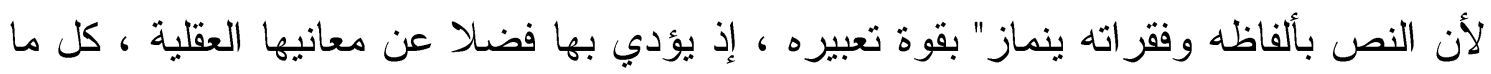

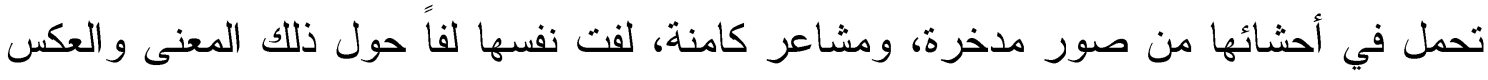

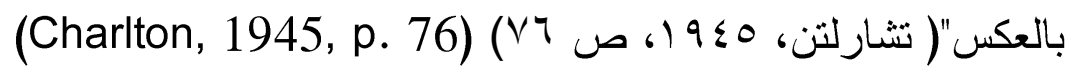

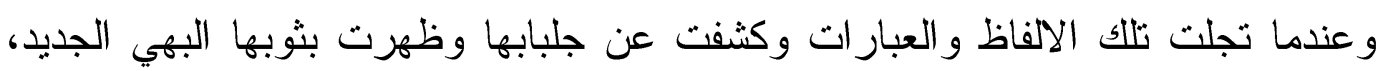
وسمّاها الباحث بمسميات تتاسب المقام، منها: - مراتب التكامل أو سلم التصاعد أو الأسفار الأربعة:

مفهوم الأسفار : مفر

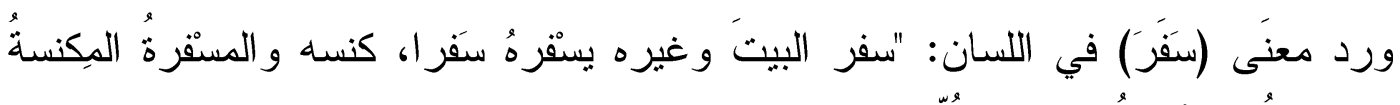

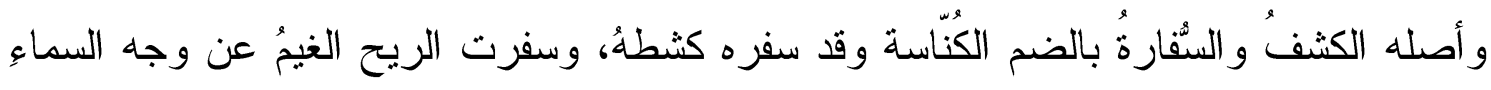

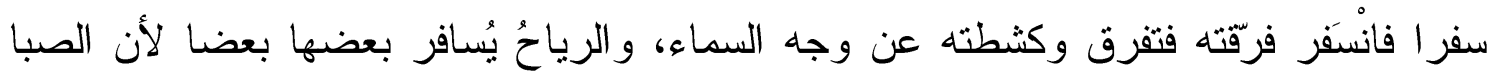

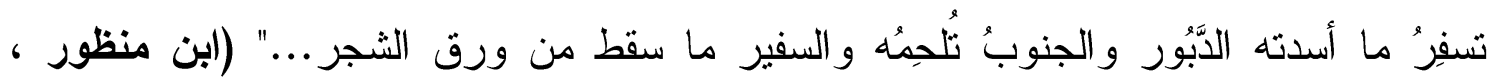

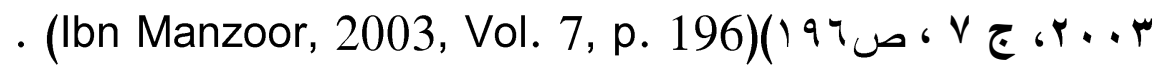


وجاء في مقايس اللغة: "رجلُ سفرُ وقومُ سفرُ، وسفرتَ بين القوم سفارةً إذا أصلحت،

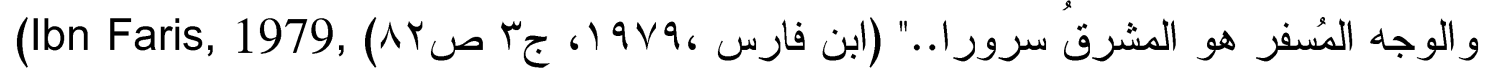

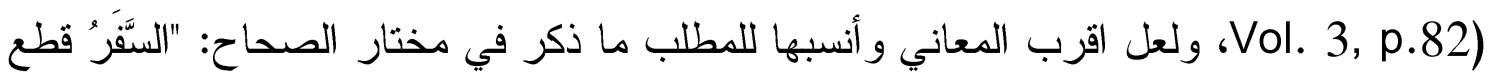

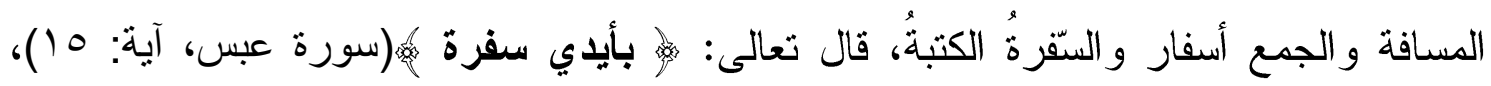

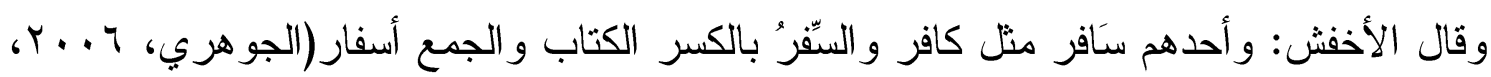

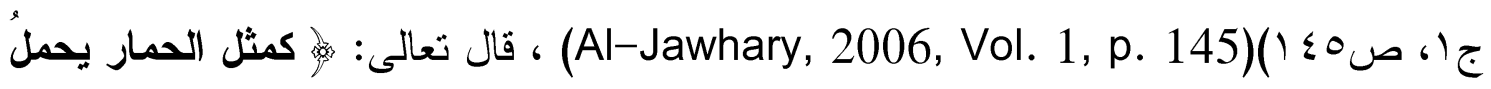

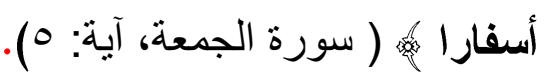

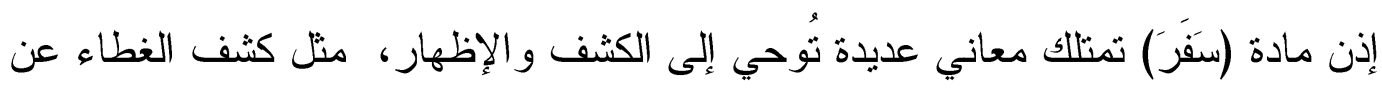

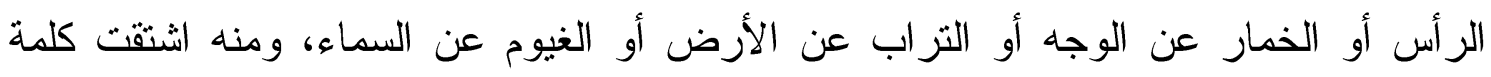

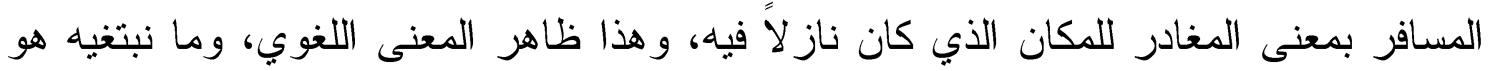
ظلال المعنى ، و هذا ما سنجده في المعنى الاصطلاحي للفظا.

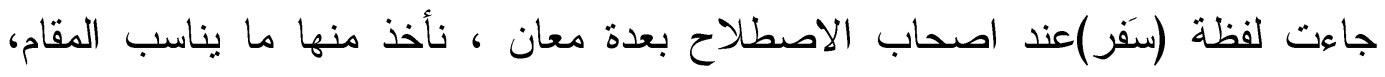

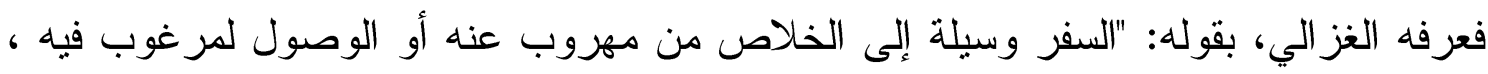

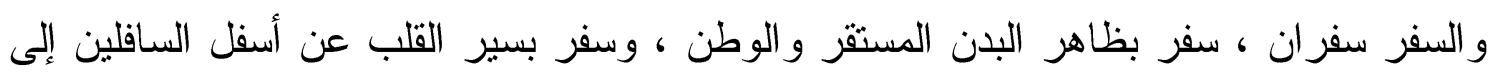

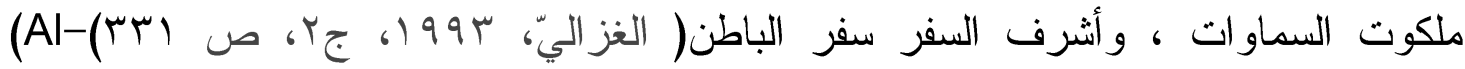

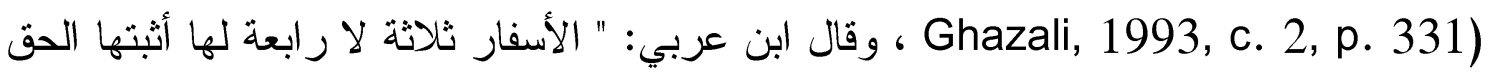

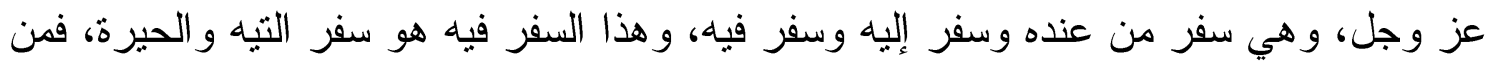

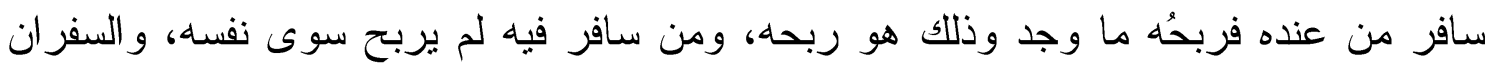

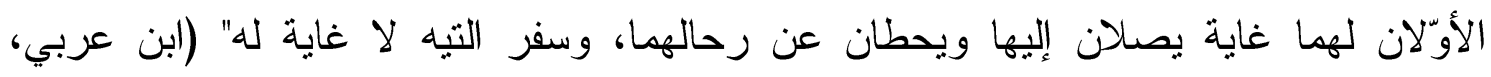

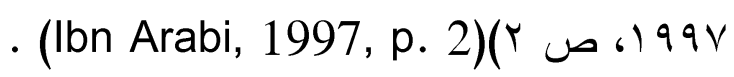
بعد هذه المقدمة المقتضبة لدفهوم الأسفار في اللغة والاصطلاح، جاء الباحث بمفهوم

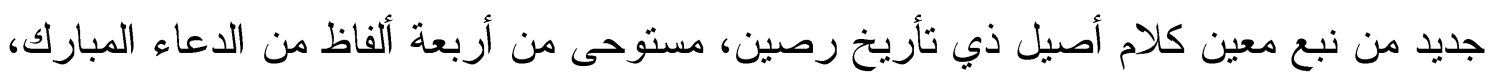

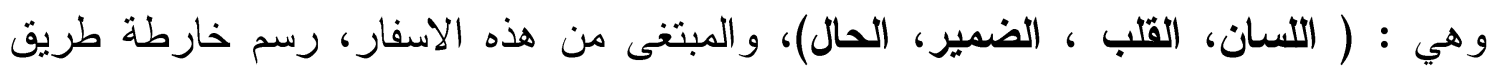

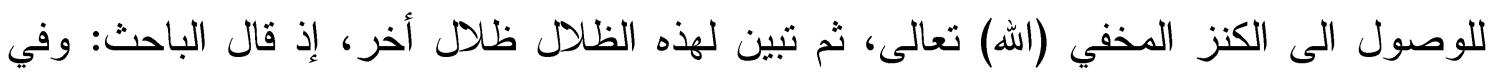

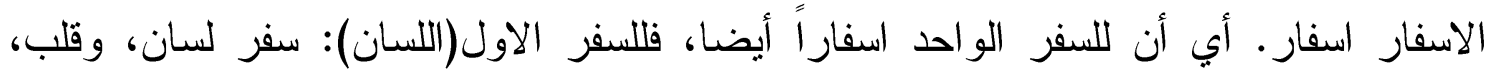

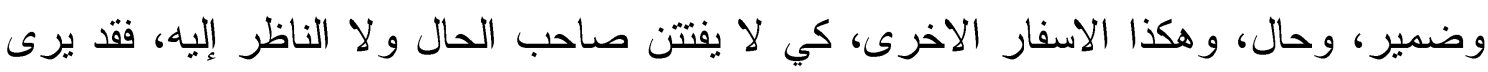
المرء نفسه في سفر الحال ولكنه ليس في السفر الاخير، و انما هو في حال من احوال الإل الاسفار

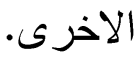


1- المقام الأول أو السفر الأول، ويطلق علبه السفر اللساني، وهو مستوحى من ظلال المعنى

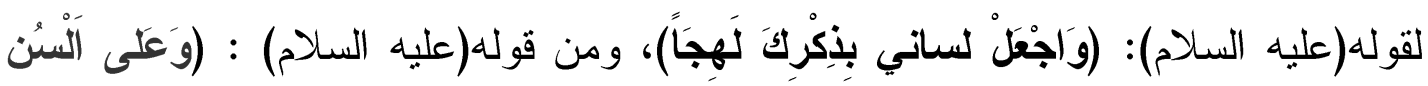

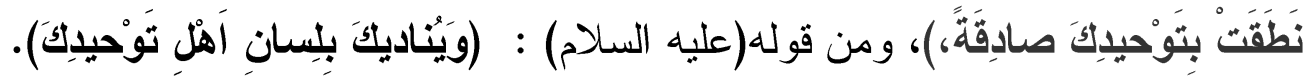

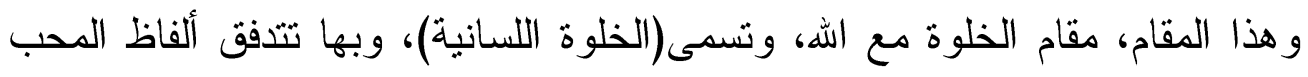

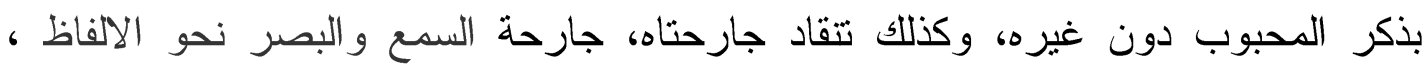

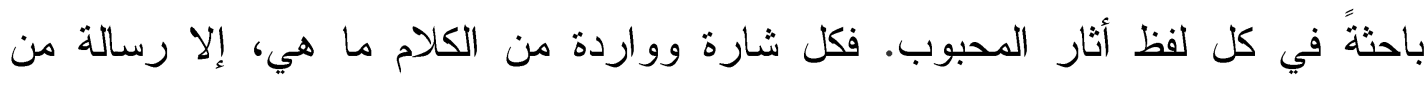

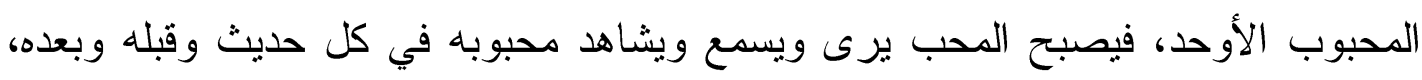

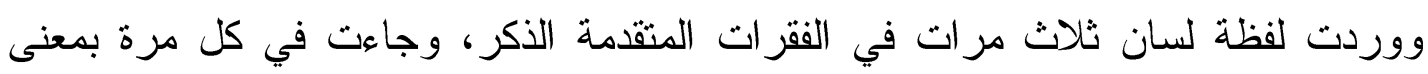

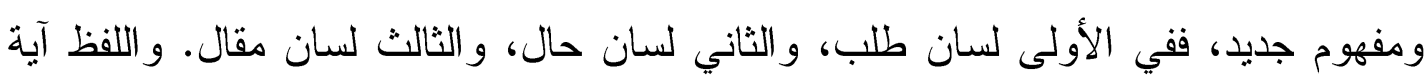

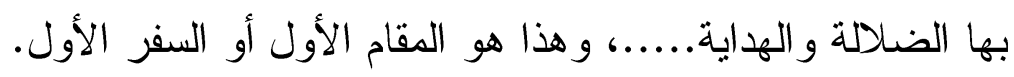

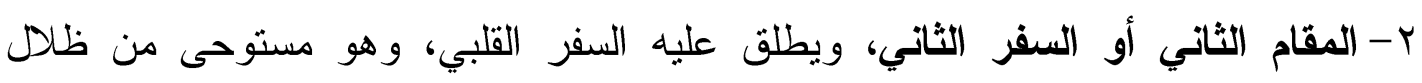

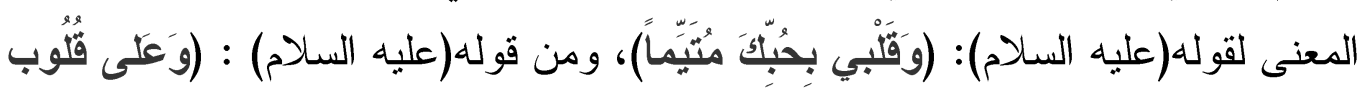

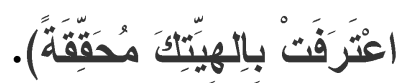

و هذا المقام أثار إليه الإمام السجاد (عليه السلام) في مناجاة الزاهدين: "واغرس

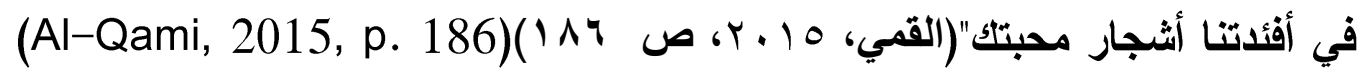

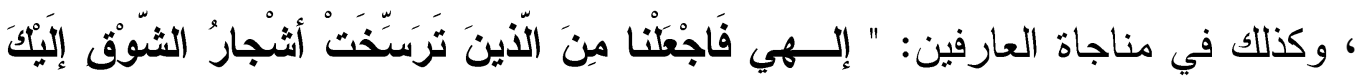

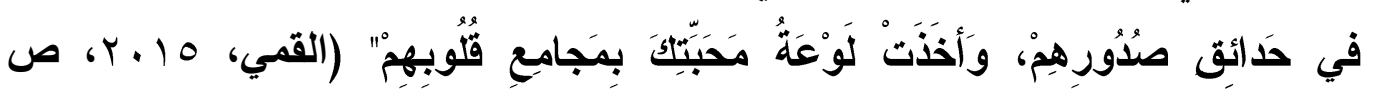

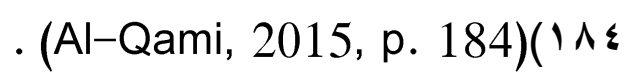

بعد تمام السفر الاول (اللساني) وكماله يتيم القلب بالدحبوب، مبتدئًا بانطباق

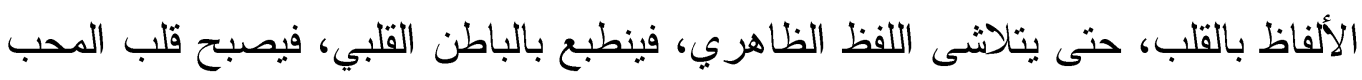

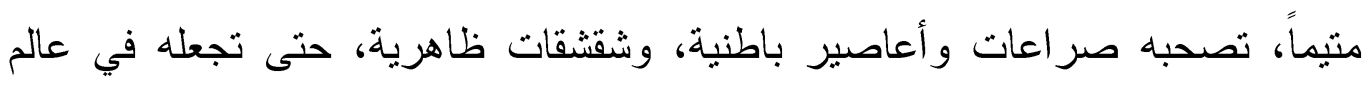

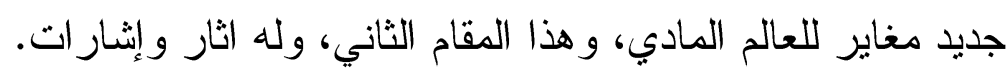

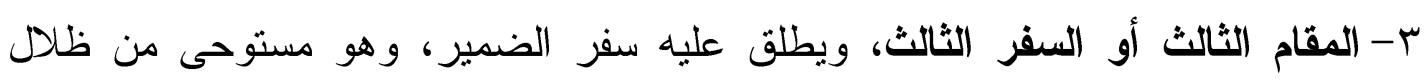

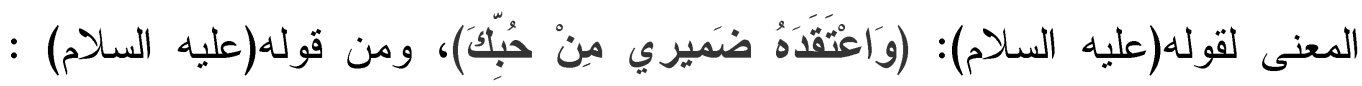

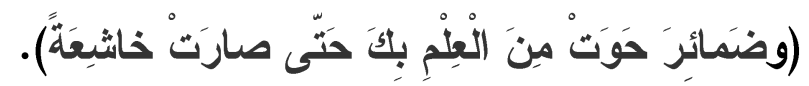

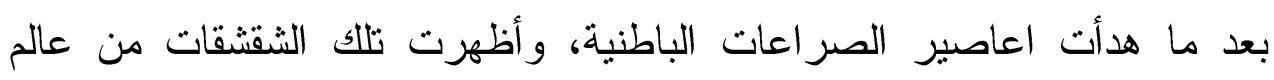

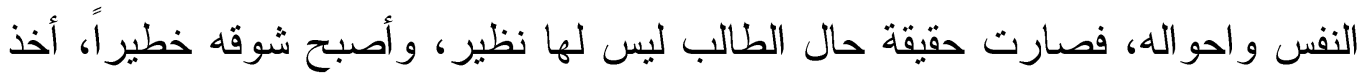
القلب لا يسعه ذلك الثوق، فانتقل من القلب إلى الضمير . 
و هذا المقام مقام الاتثقال من الباطن القلبي الى باطن الباطن.... وهو مقام الدهش و الانبهار و التعجب و الصدمة و التوقف و السكون و الحيرة، وهو مقام مغاير للمقامين السابقين، وكذلك للمقام اللاحق الاخير • وبه تحصل الخلوة باله تبارك وتعالى.

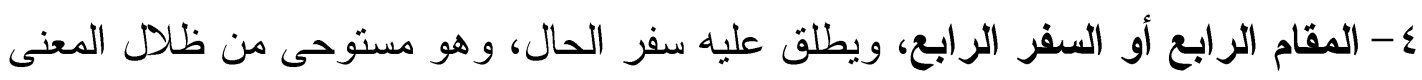

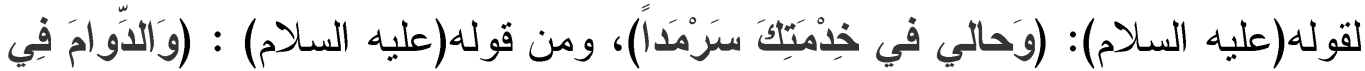

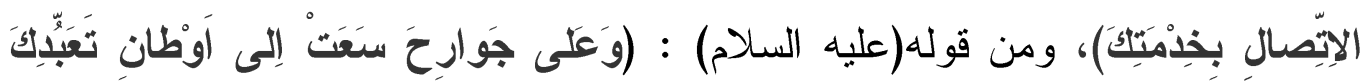

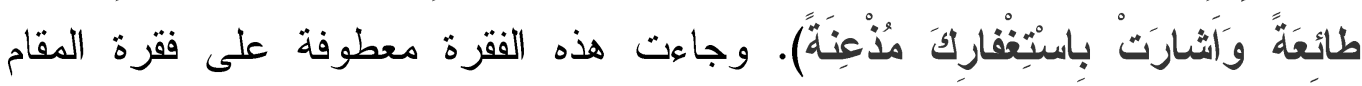

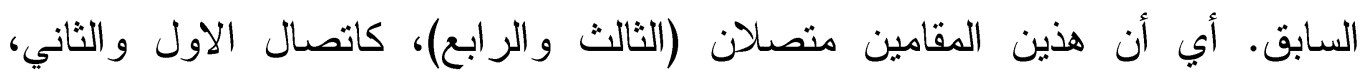

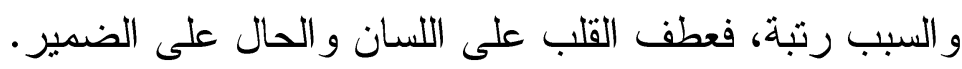

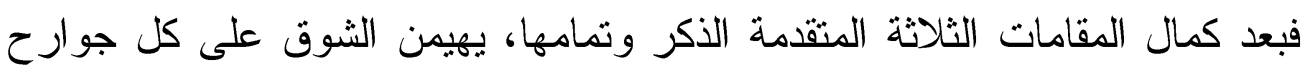

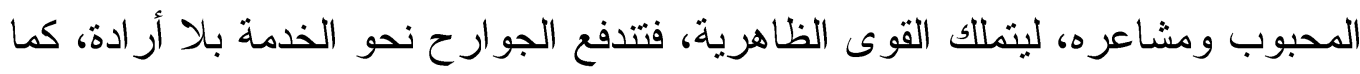

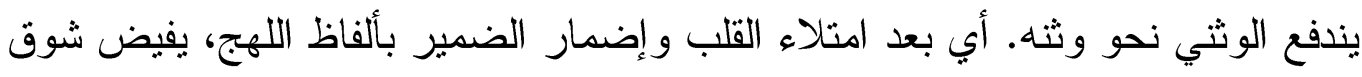

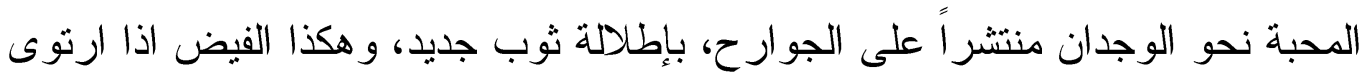

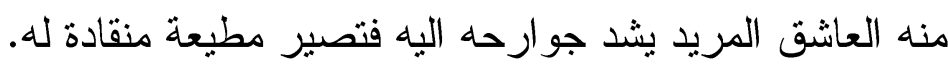

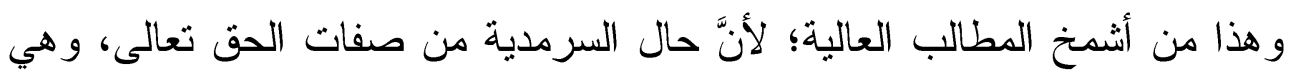

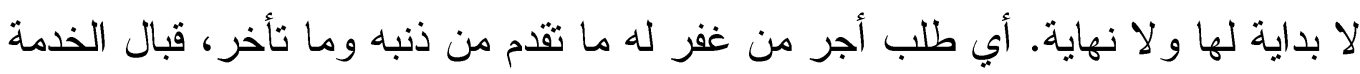

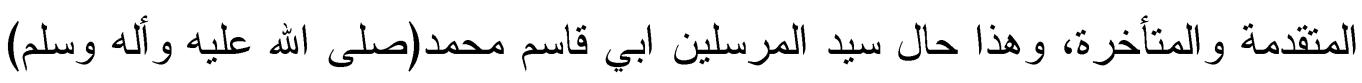

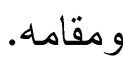

هذا هو السفر الاخير، وهو مقام الفيض والعطاء والخدمة، وبه الافعال أبي افعال

$$
\text { العاشق تكون سجايا بلا تكلّف، كسجية الكرم و الثجاعة. }
$$

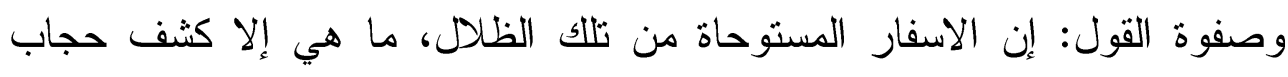

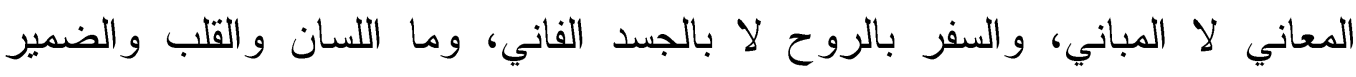

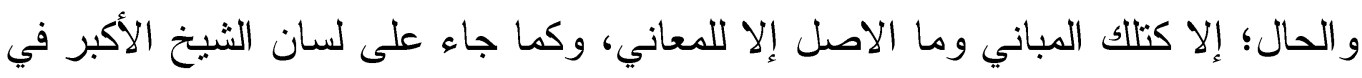

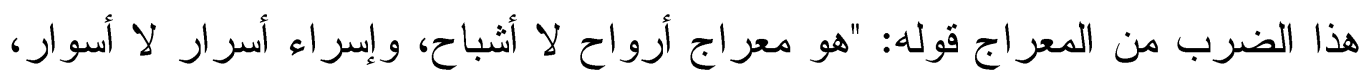

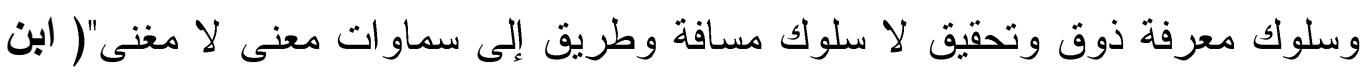

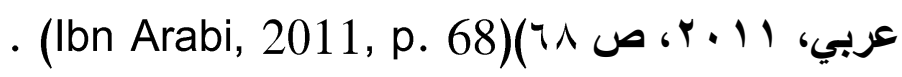




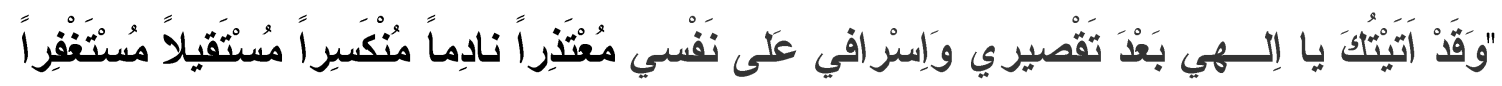

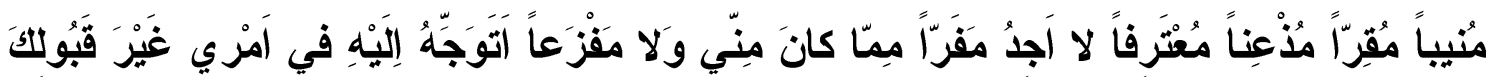

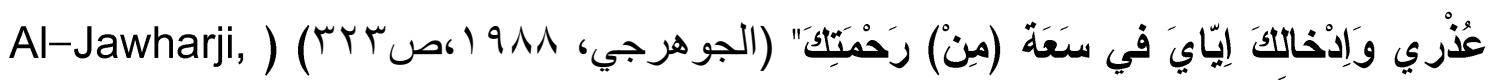
.(1988, p. 323

نلحظ وبوضوح جلي أن في النص تسعة ألفاظ ، ألا وهي: (الاعتذار و الندم والانكسار

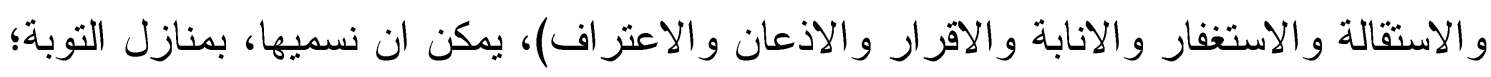

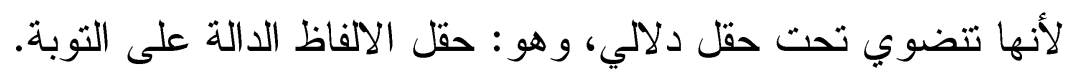

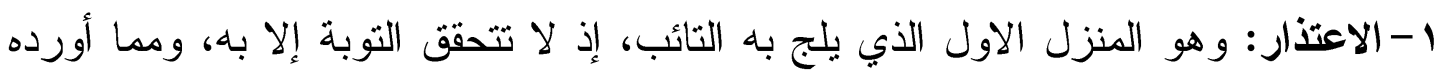

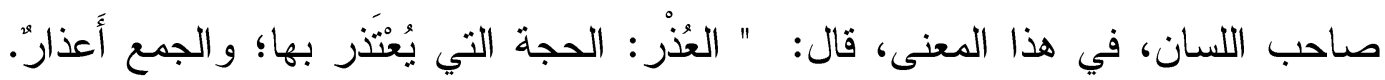

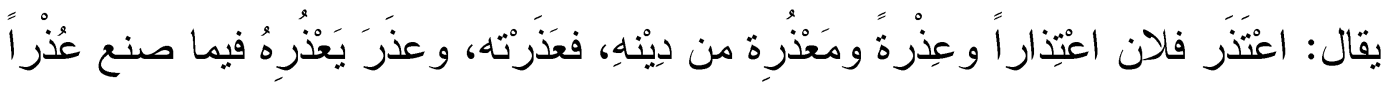

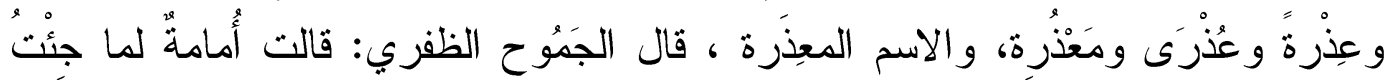

$$
\text { زلائَ هَها: }
$$

لو لا حُدِدْتُ، و لا عُدْرَى لِمَحْدودِ

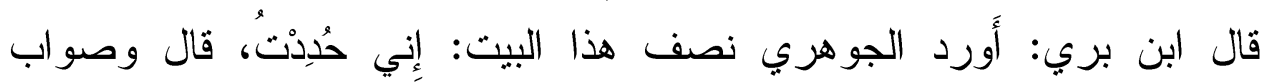

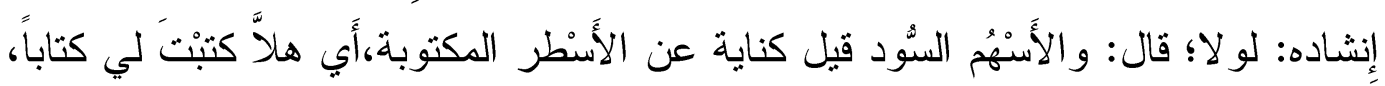

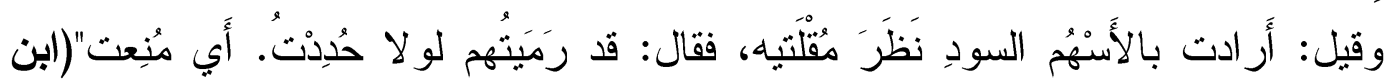

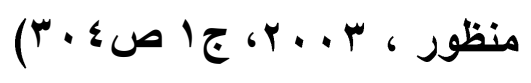

.(Ibn Manzoor, 2003, , Vol. 6, p. 304)

r- الندم: وهو المنزل الثاني الذي يلج فيه الثائب بعد منزل الاعتذار، وقد يمثل الاول ظاهر

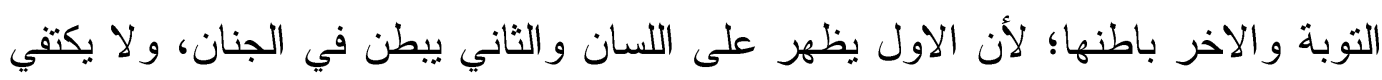

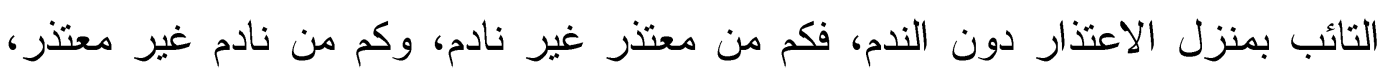

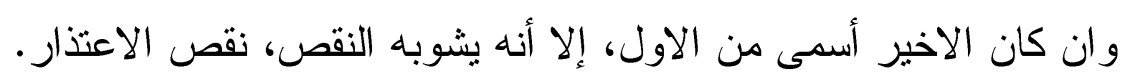

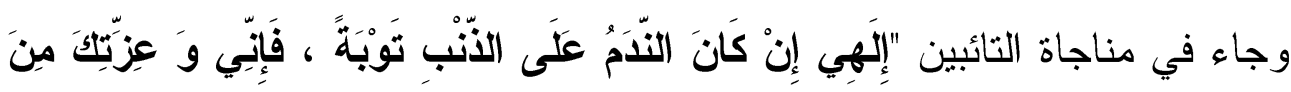

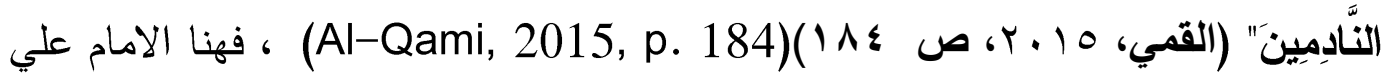

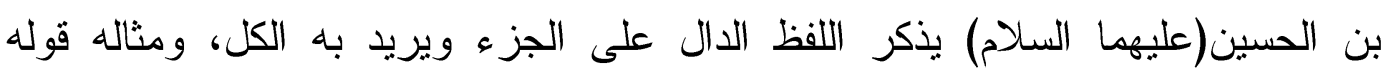

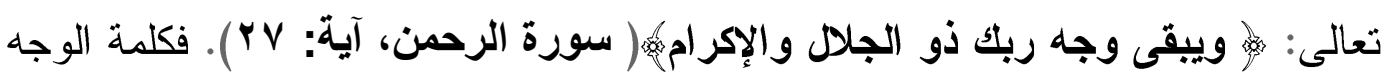


في الآية المر اد بها الذات القدسية لله تعالى ... يتبين من الكلام المتقدم أن من دخل هذا

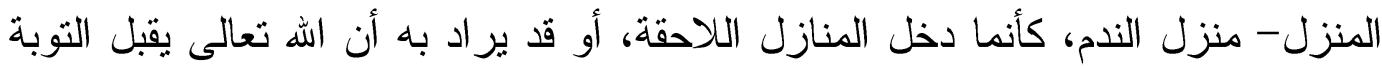
من عبده العاصي، وإن حط رحاله في هذا المنزل فقط.

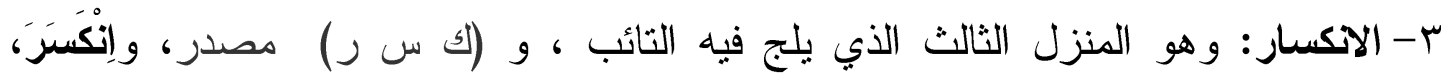

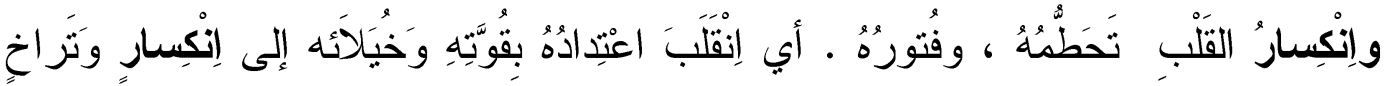

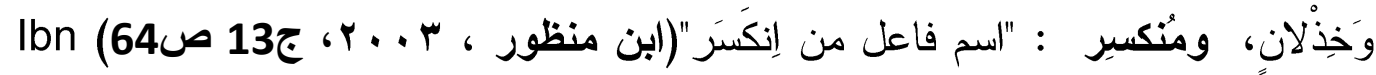
(Manzoor, 2003, , Vol. 13, p. 64)

وقال الغز الي: "يكسر به شهوة النفس التي تعاديه، فيدفع شرها ثم يعبد ربه ويتقيه،

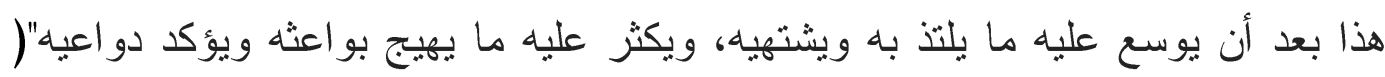

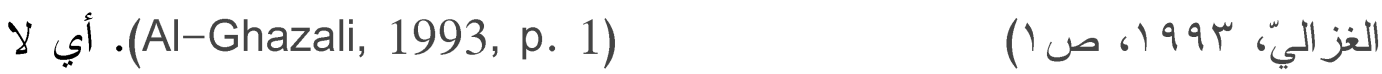

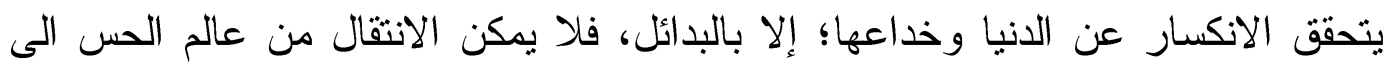

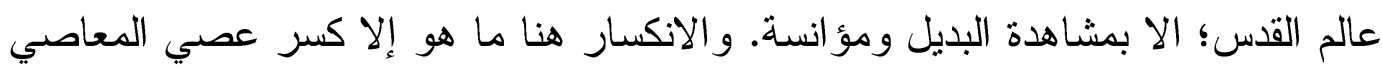
بعد الاعتذار و الندم.

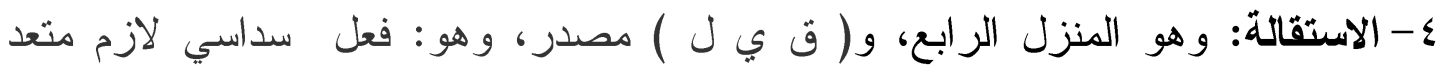

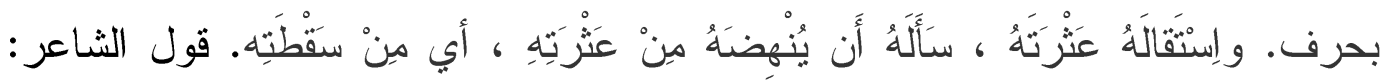

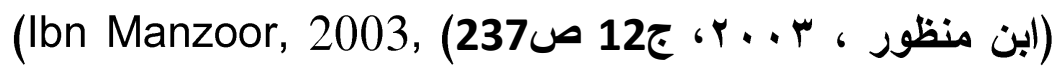

Vol. 12, p. 237)

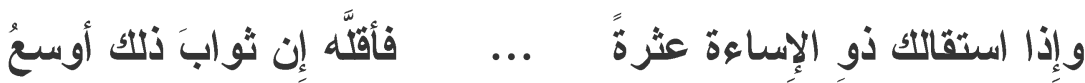

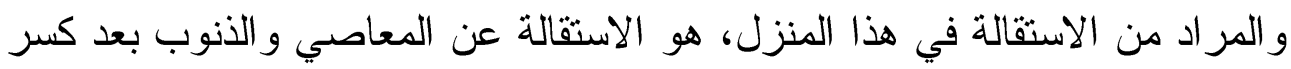
عصاهما ، و هذا المنزل أقرب للتوبة من المنازل السابقة.

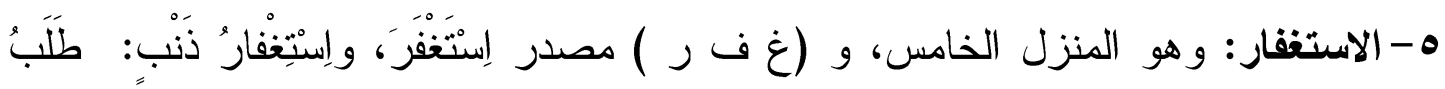

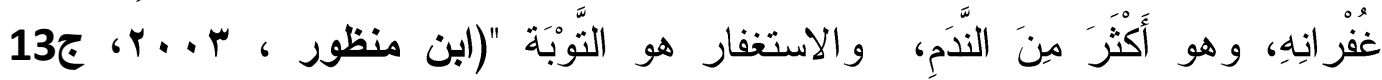

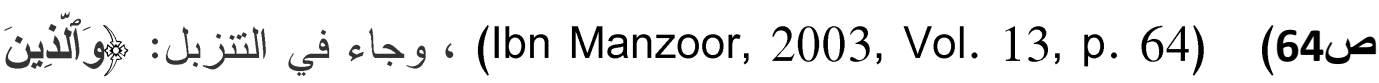

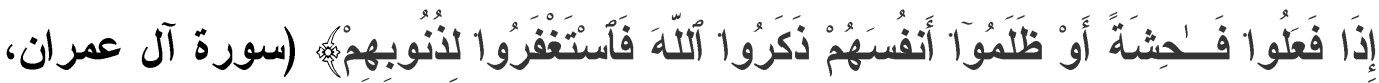

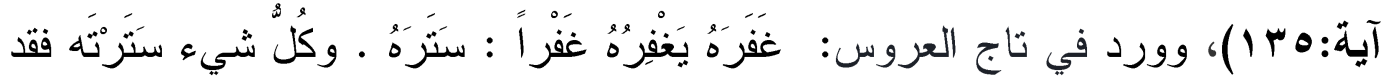

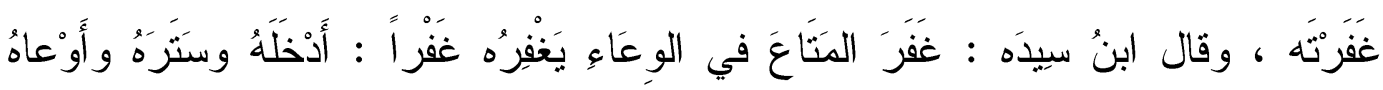

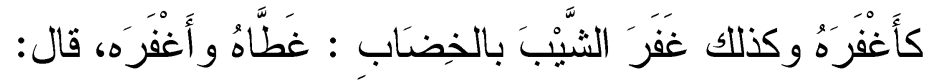

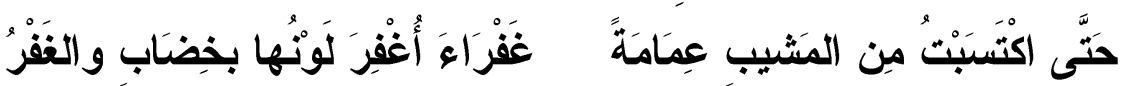




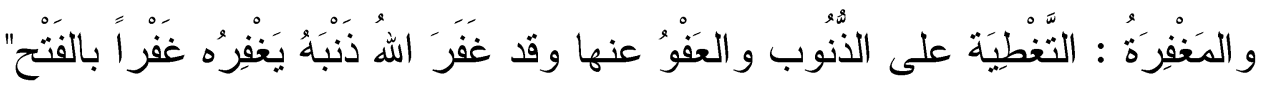

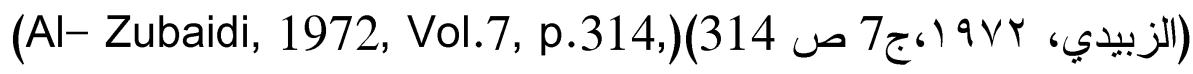

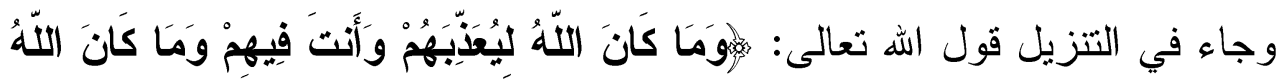

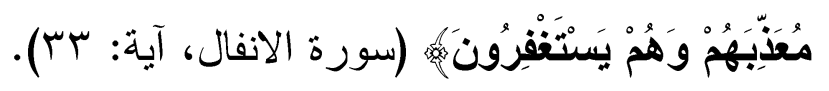
اخرج الترمذي عن أبي موسى الأشعري، قال: قال رسول اله الهُ (صلى الله عليه

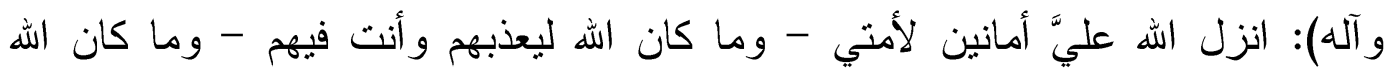

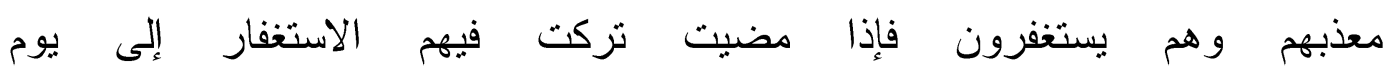

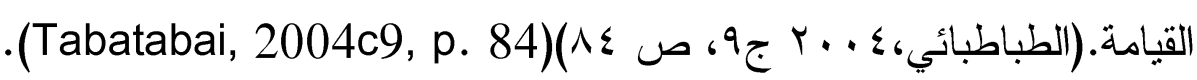
الاستخفار حِّة من الذنوب، لما ورد في تثمة الفقرة السابقة من مناجاة التائبين

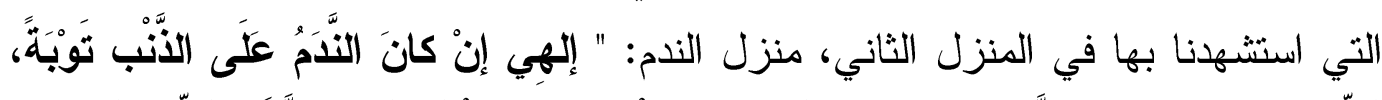

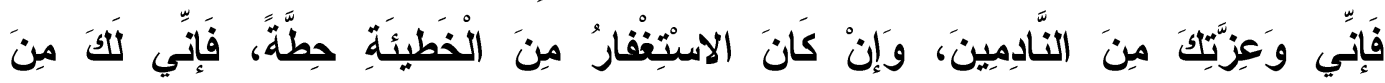

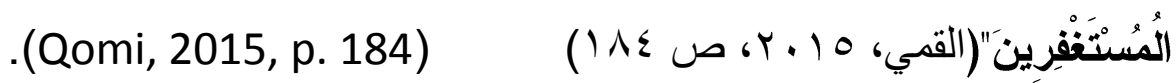

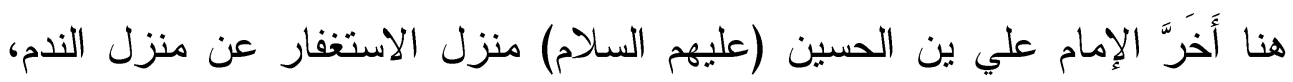

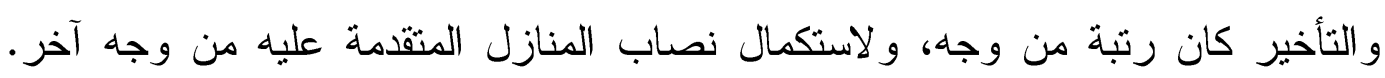

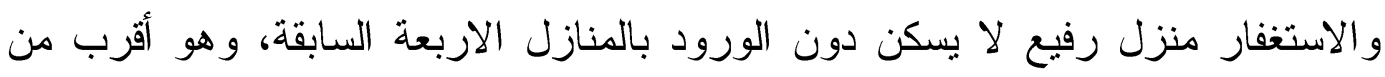
الحق وتلك المنازل هي اقرب الى الى الخلق. צ- الاتابة: هي المنزل السادس، و (و النون، و الواو ، و الباء) كلمة واحدة تدلّ على اعتياد مكان

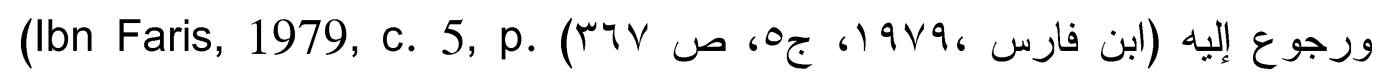

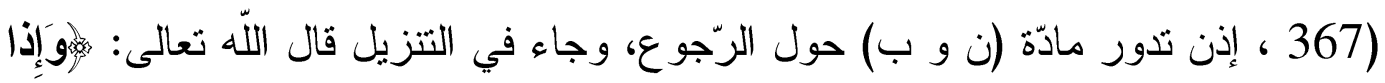

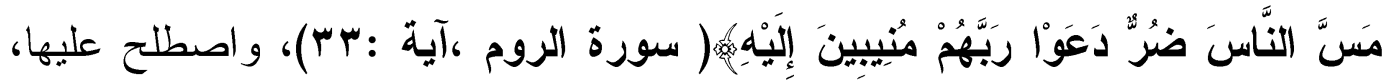

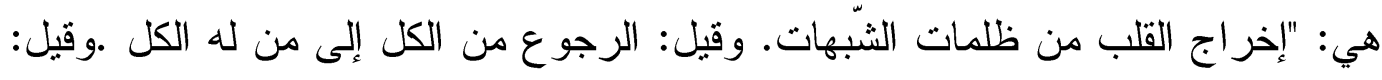

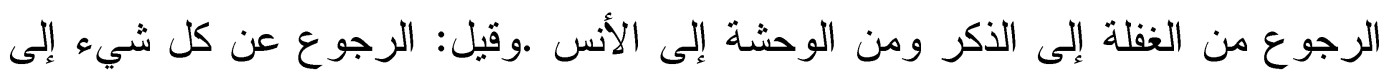

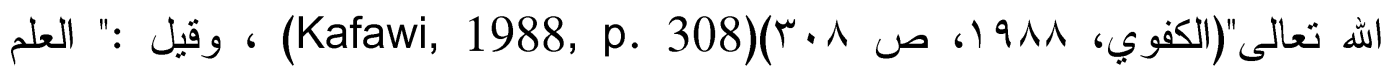

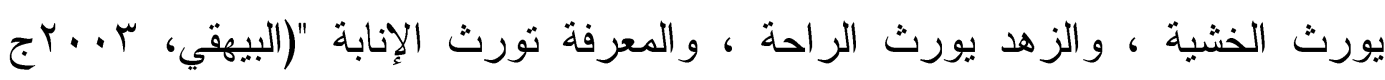

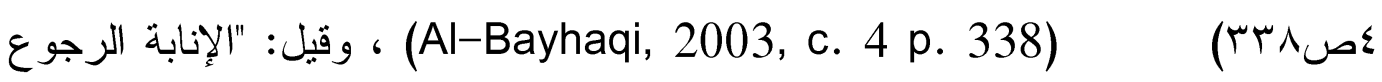

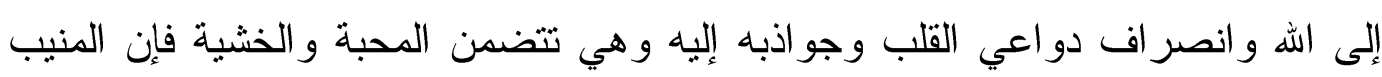

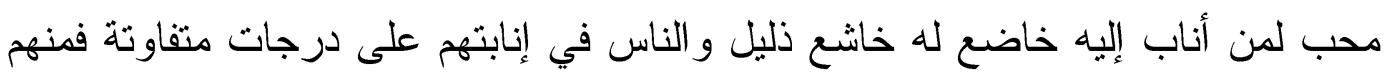

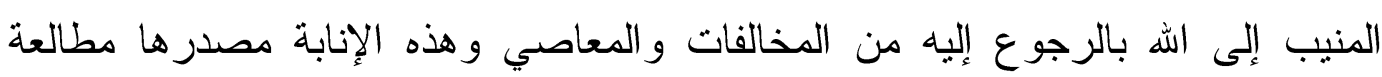




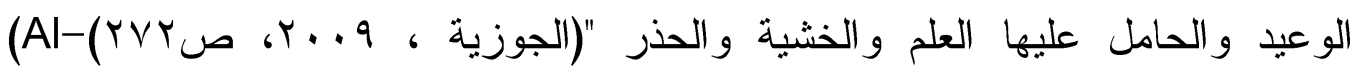

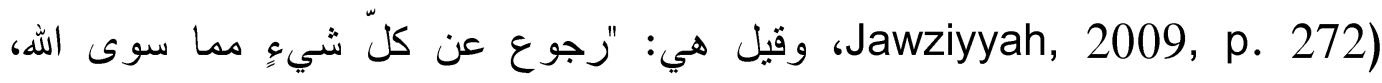

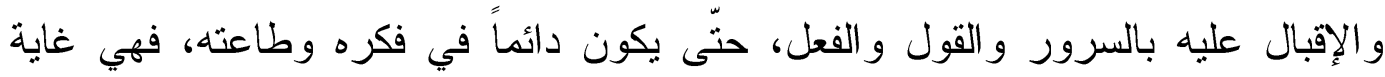

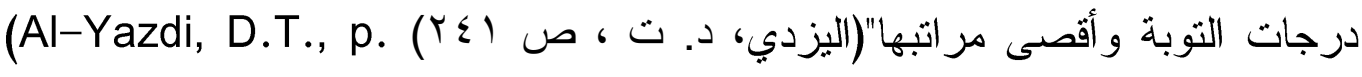

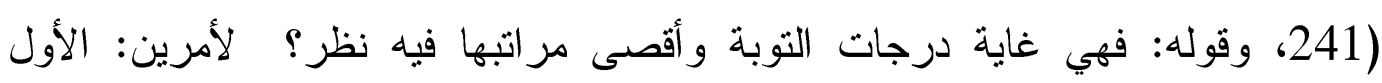

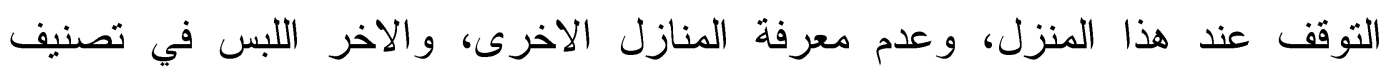

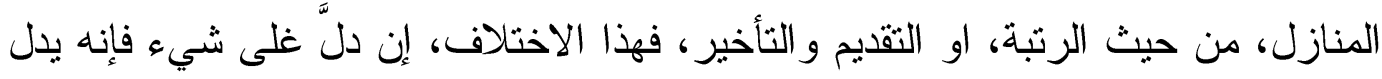

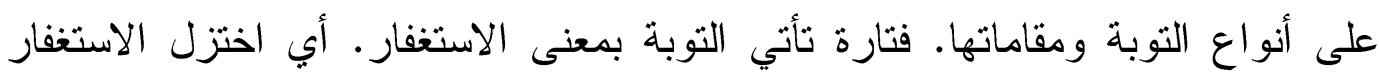

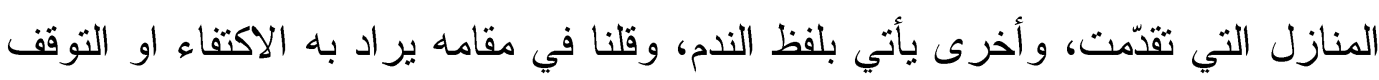

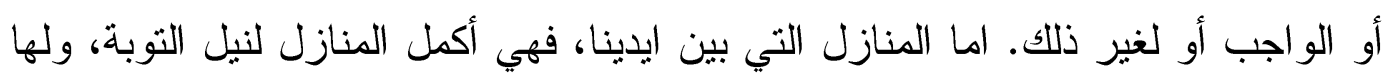
ظاهر وباطن. - مان.

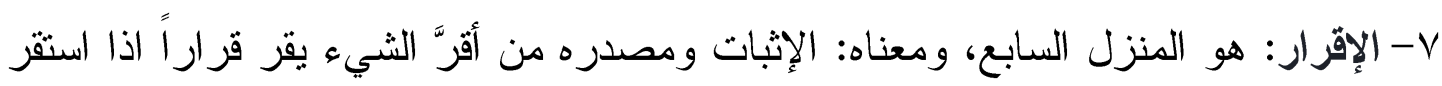

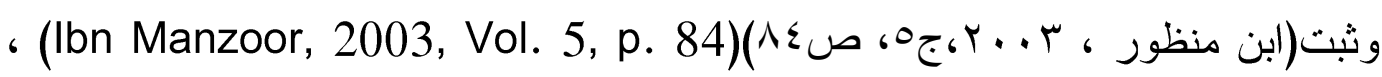

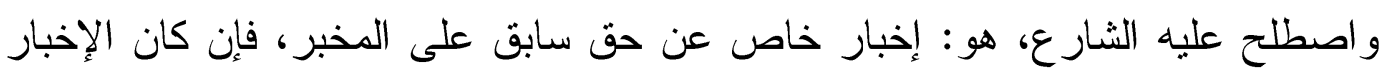

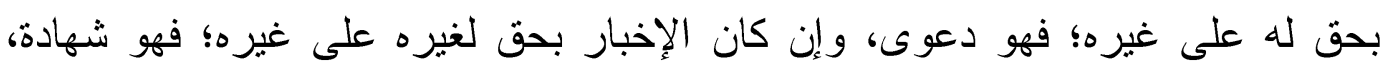

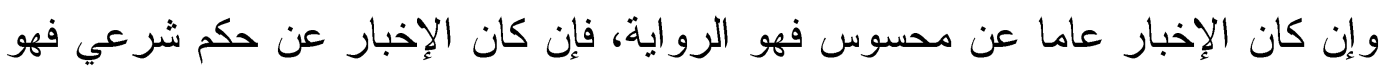

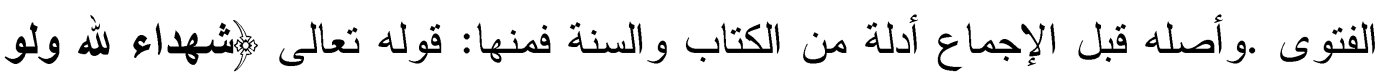

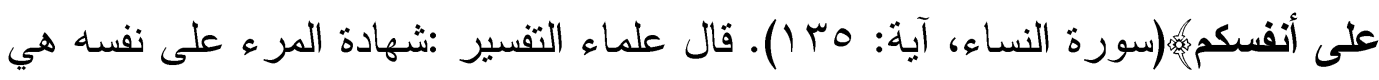

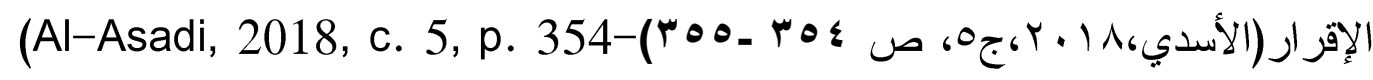

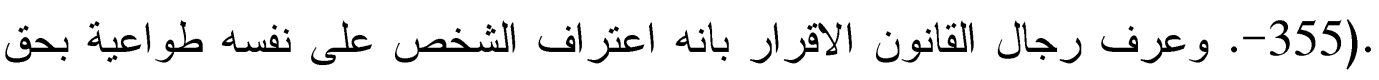

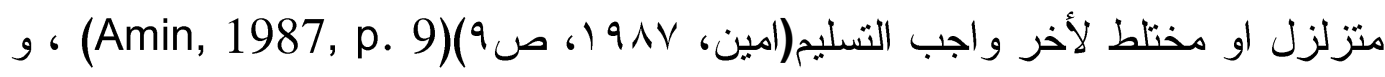

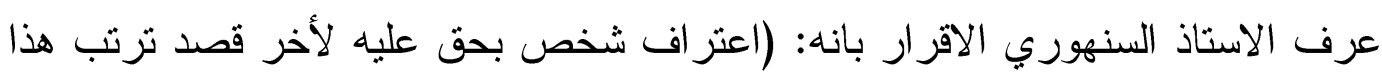

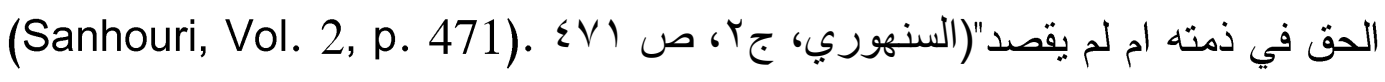

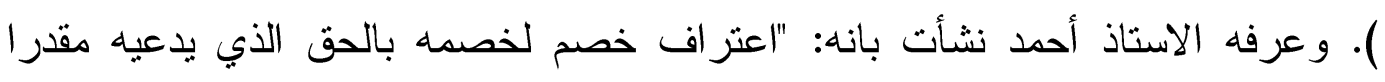

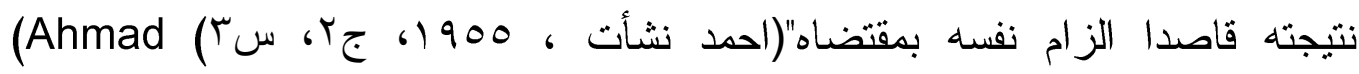
Nashat, 1955, c. 2, p. 3) و السنة النبوية المطهرة والاجماع و المعقول. 
و الاقرار هو من الحجج الباطنية ، لأنه رفع الوساطة بينه وبين الحق (جل شأنه)،

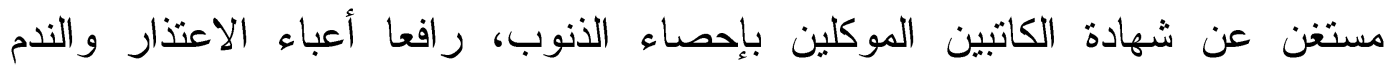

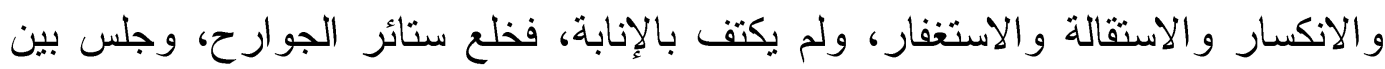

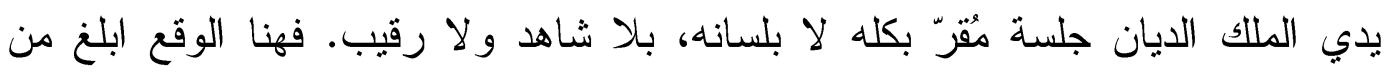

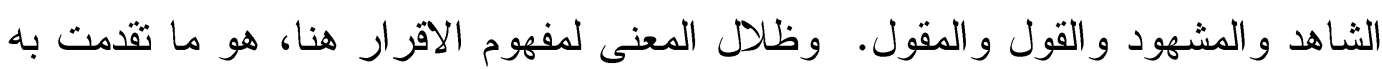
المنازل السابقة، فلا لبس و لا غموض و ولا الشتباه.

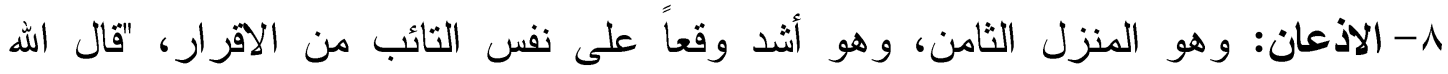

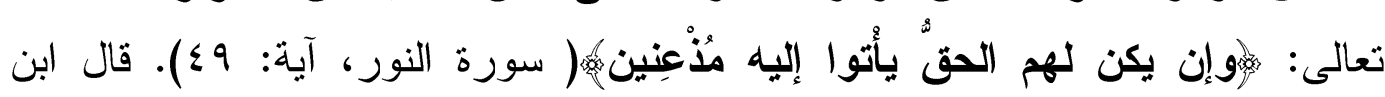

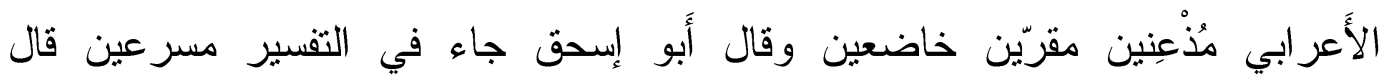

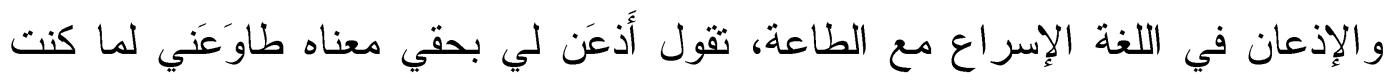

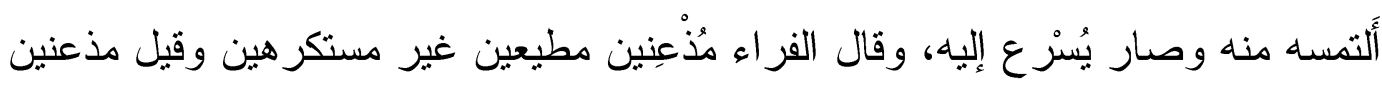

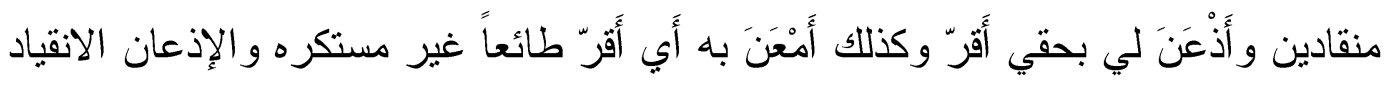

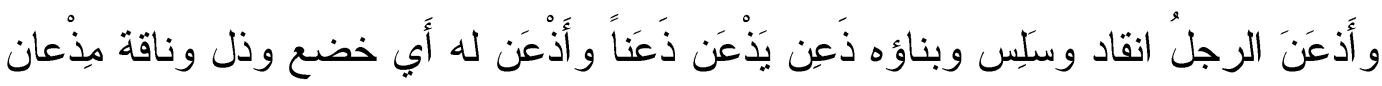

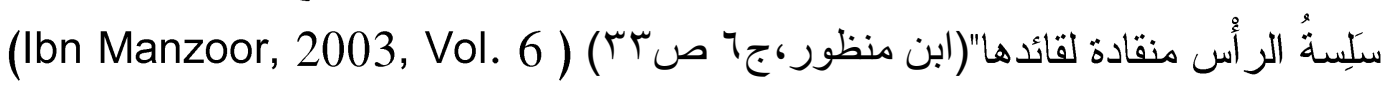

ونلحظ أن هناك فروقات لغوية لبعض الالفاظ لم ثقف عندها معجمات اللغة العربية،

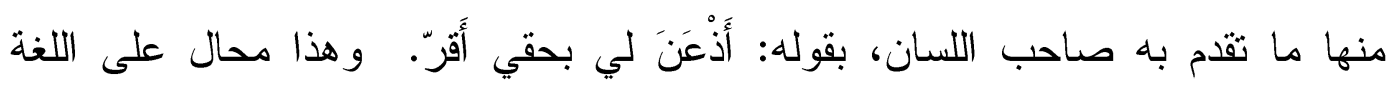

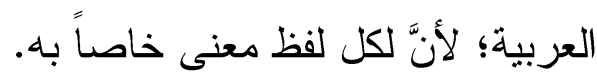

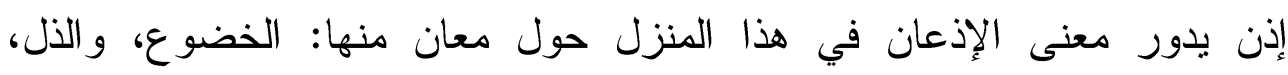
و الانقياد السلس، والإسر اع مع الطاعة، والاخير هو الاصدوب هو والإنرب للمقام.

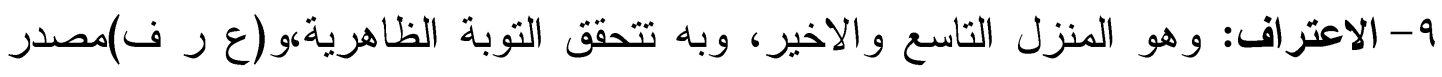

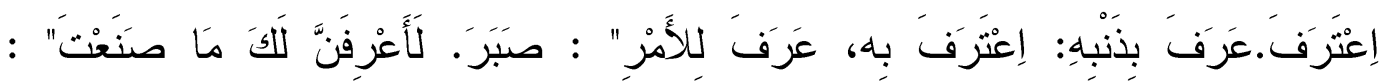

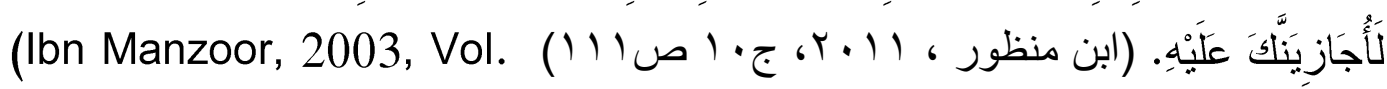
$.10 \mathrm{p} \mathrm{111)}$

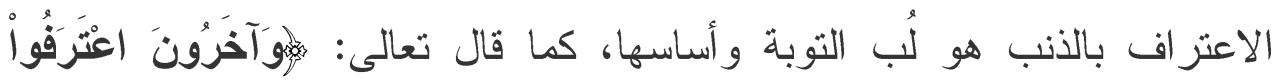

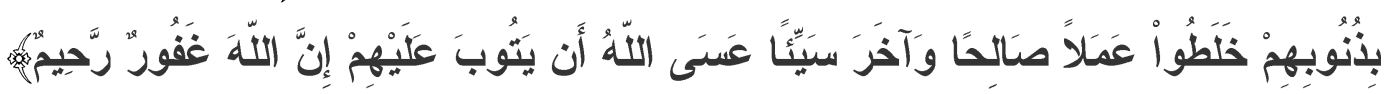

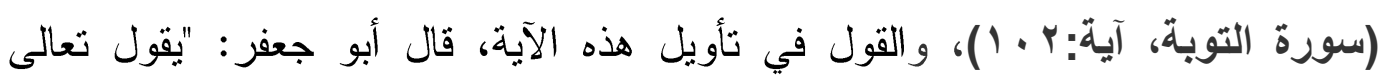


ذكره: ومن أهل المدينة منافقون مردوا على النفاق، ومنهم آخرون اعترفوا بذنوبهم،

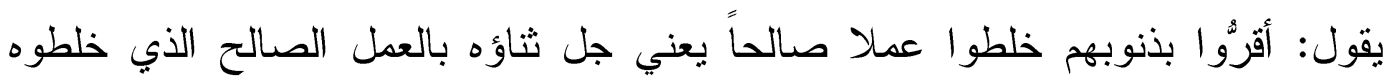

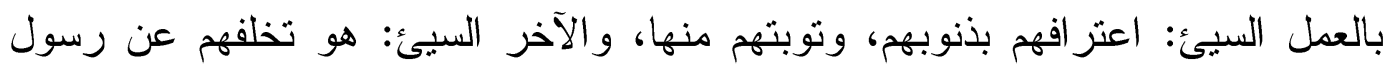

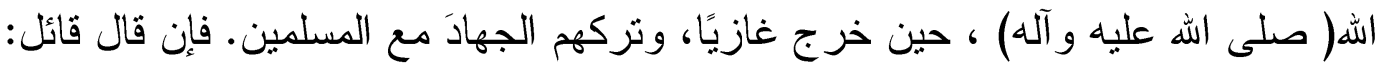

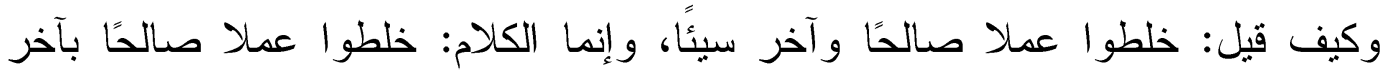

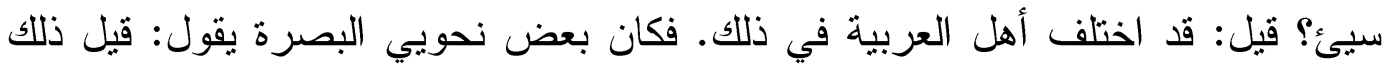
كذلك، وجائز في العربية أن يكون بآخر، كما نقول: استوى الماء والخشبة، أب: بالخشبة، وخلطت الماء و اللبن، و أنكر آخر أن يكون نظير قولهم: استوى الماء و والخشبة،

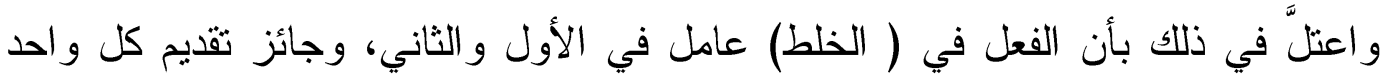

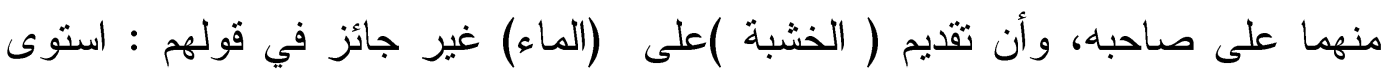

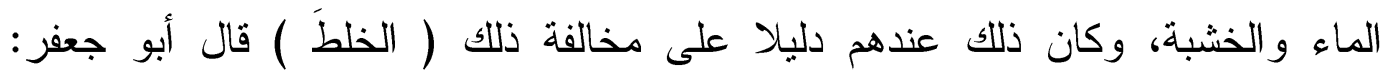
و الصواب من القول في ذلك عندي: أنه بمعنى قولهم: خلطت الماء و اللبن، بلى بمعنى:

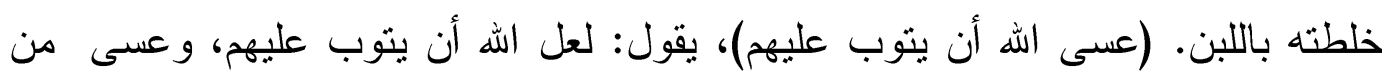

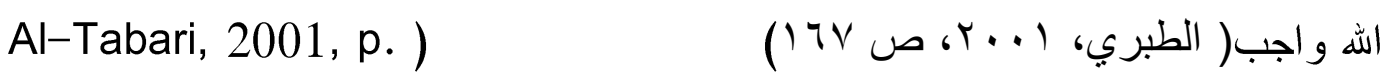
167)، و إنما معناه: سيتوب الله عليهم، ولكنه في كلام العرب على ما وصفت إلى إن الله

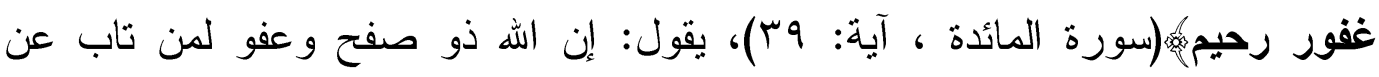

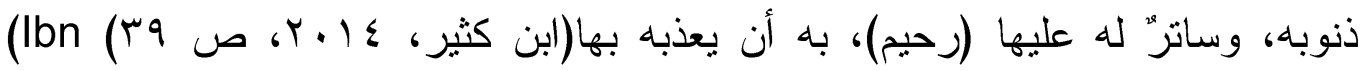

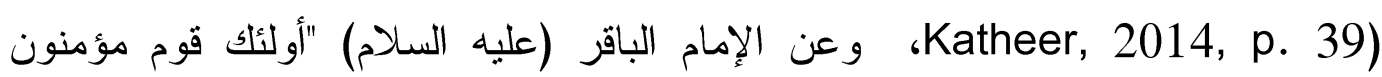

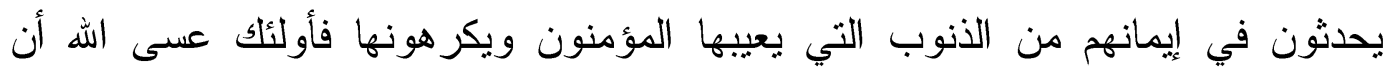

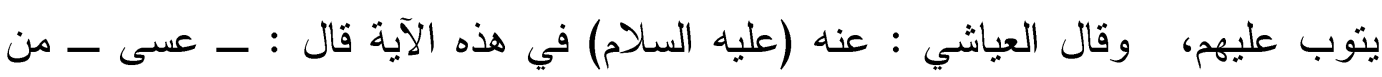

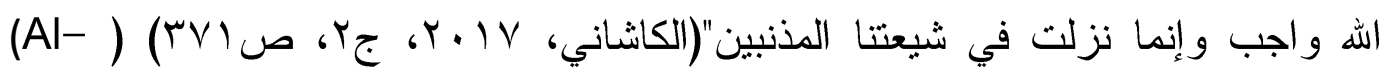
Kashani, 2017, Vol 2, p. 371

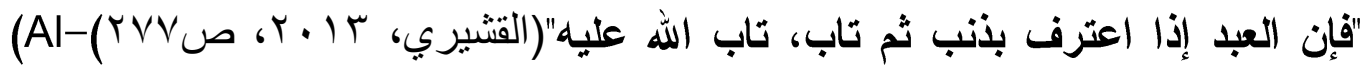
.Qushayri, 2013, p. 277) ومن الشقشقات التي استوحتها ظلال المعاني من بعض ألفاظ النص، أن الدعاء

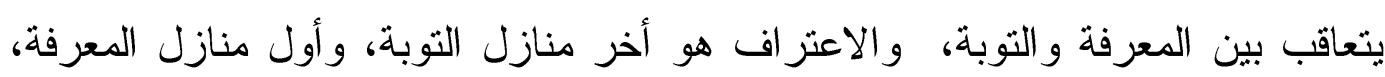

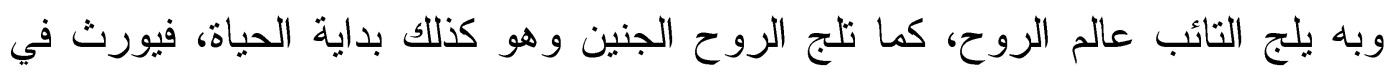


النفس صفاءً ونقاءً وطهارةً مستمرة، بعدم تدنيس الانفس بمدلهمات ثياب الذنوب

$$
\text { و المعاصي. }
$$

وصفوة القول: أن ظلال المعاني التي وسمت بــ(منازل التوبة)، وقيدت بتسع منازل

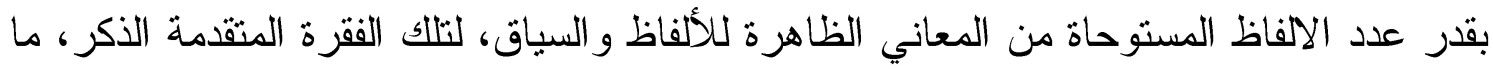

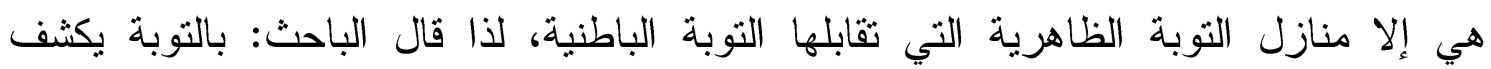

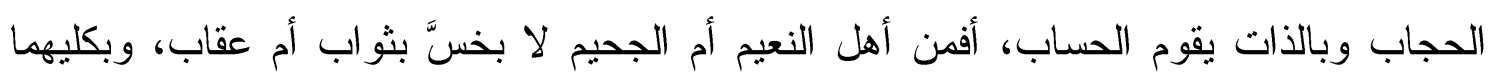

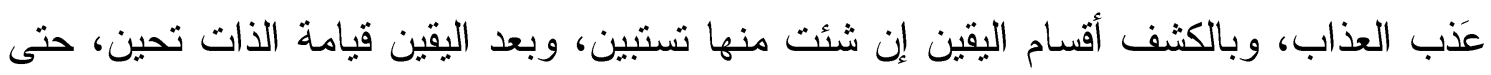
تجمع الاضداد: تيه برشاد، وجحيم بنعيم، وشك بيقين.

$$
\text { - مأحوال أهل القرب ( الجذب): }
$$

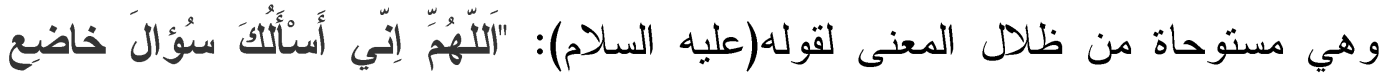

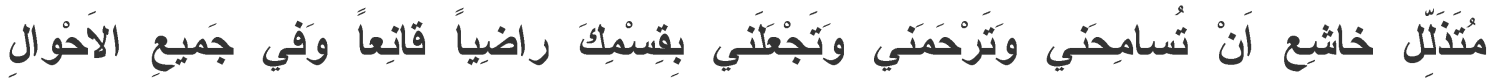

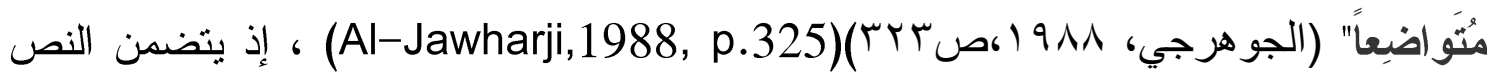

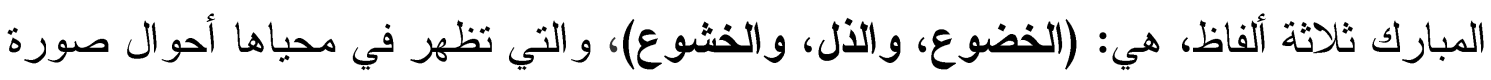

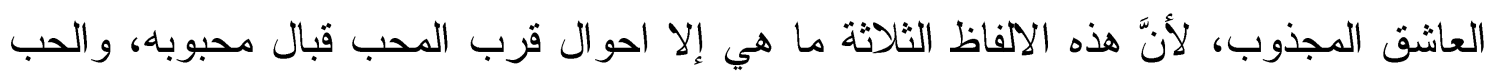

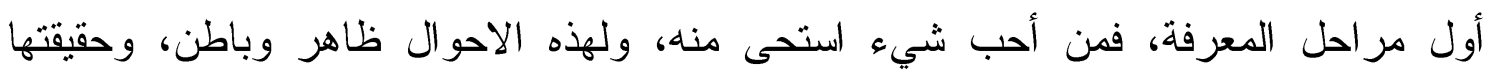

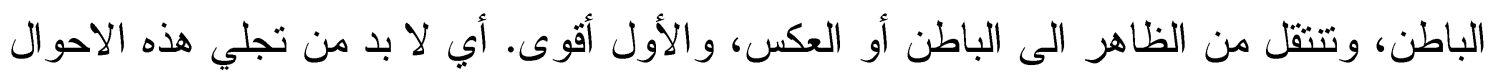

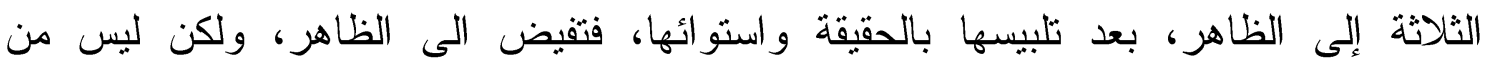

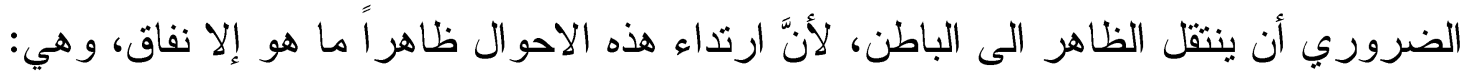

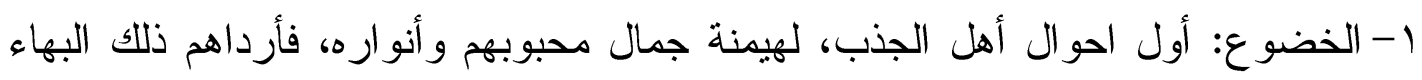

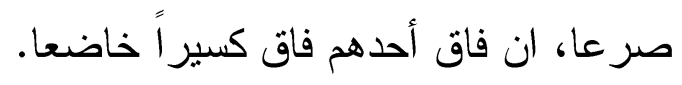

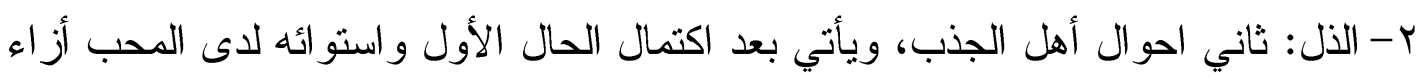

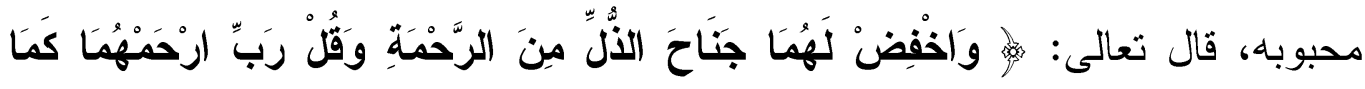

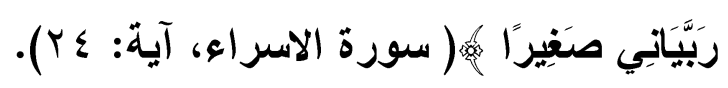

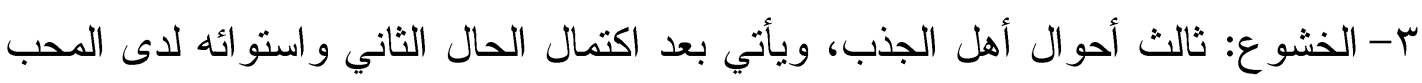

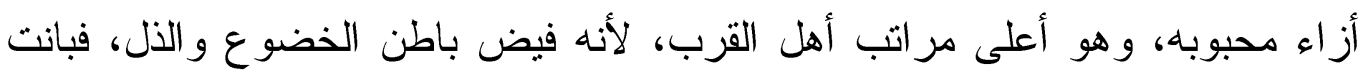

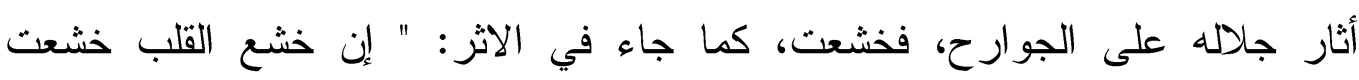

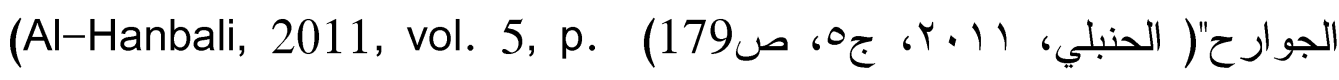


(179، وجاء في حديث المعراج: " ما عرفني عبدي وخشع لي؛ الا وخشعت له"

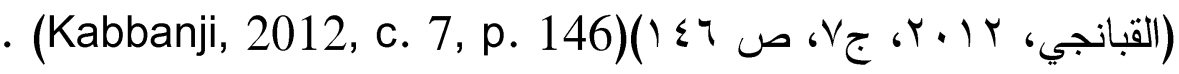

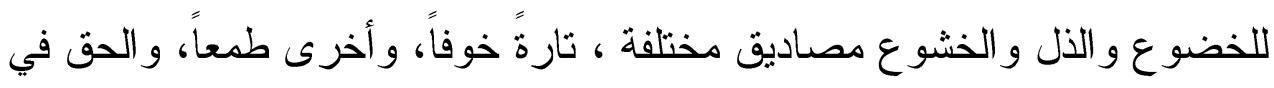

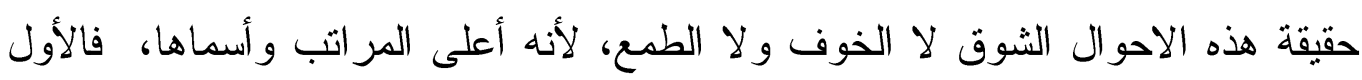

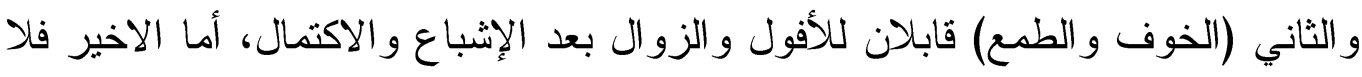

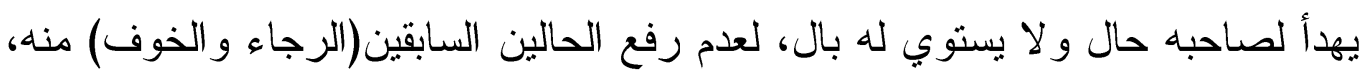

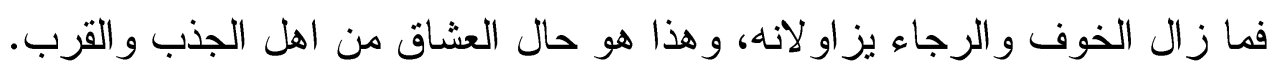

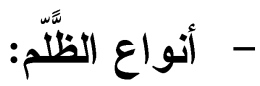

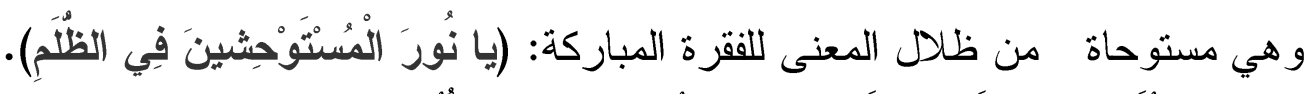

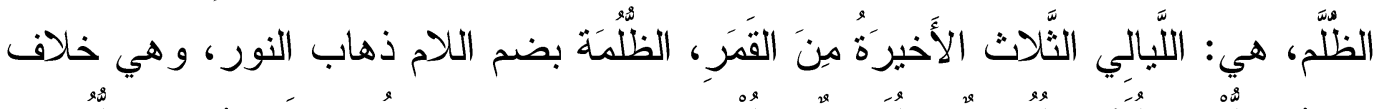

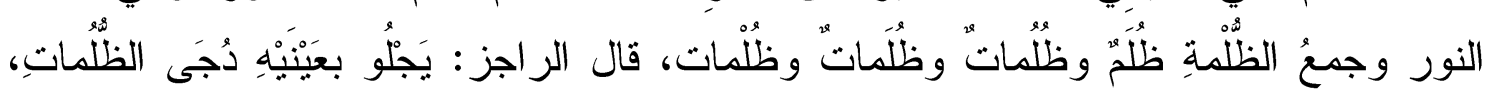

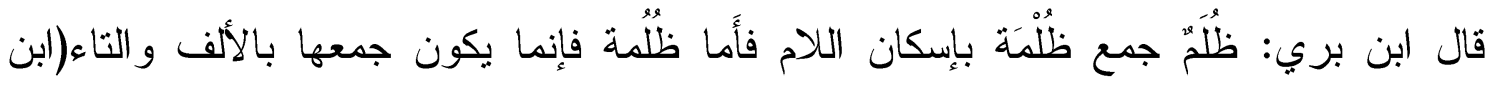
Ibn Manzoor, 2003, Vol. 11 p

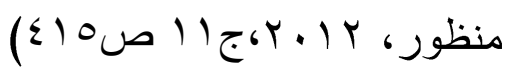

بدأ الطالب يتخلص من تلاطم ظلمات أعاصير السخط و النقمة، حتى رأى فأبصر ..... إنه لا نفاذ من هذه القيود (قيود الحبس و الظلمة) إلا به ومنه و اليه، فنادى بطلب النجدة منها، فهو المنقذ و المنجد و المساعد، و الهادي، وهو البداية و النهاية، بل هو النقاد النطة.

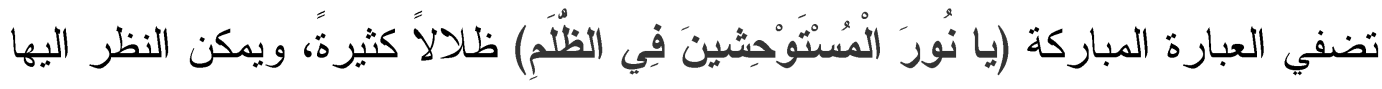

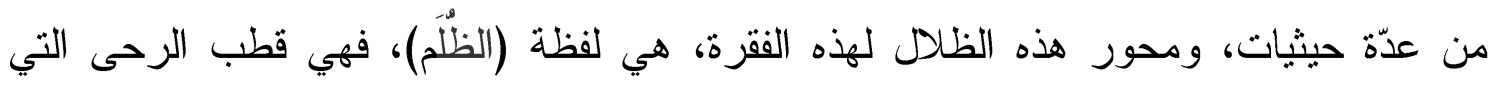

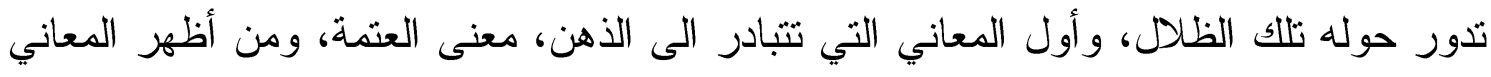

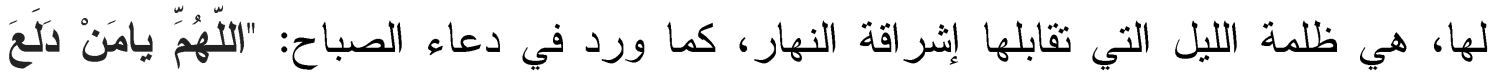

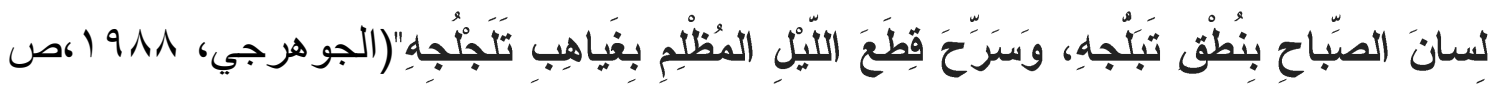
- (Al-Jawharji, 1988, p. 240)( r .

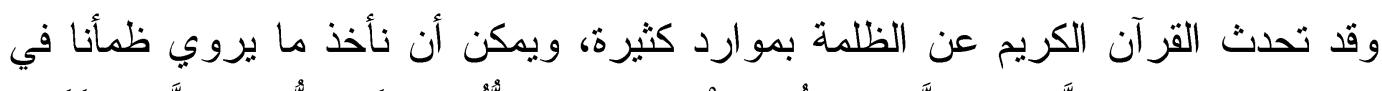

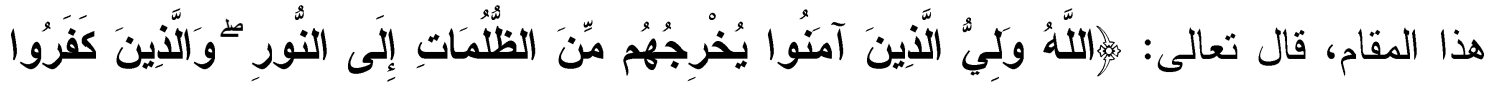

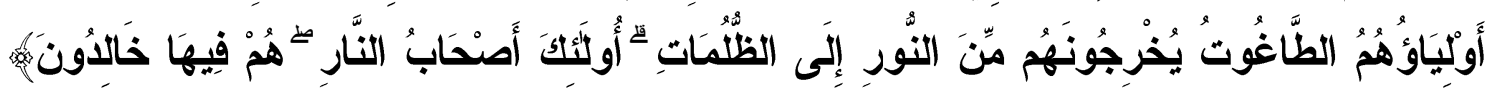

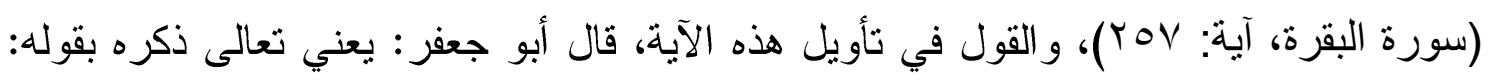




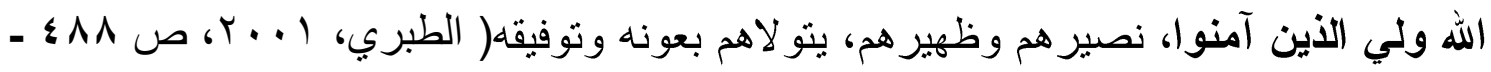

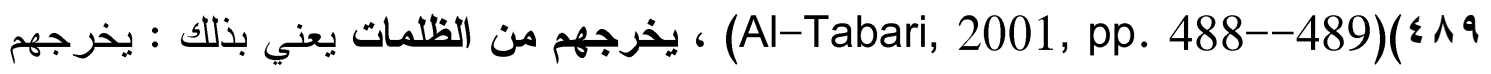
من ظلمات الكفر إلى نور الإيمان. و إنما عنى ب(الظلمات ) في هذا الموضع، الكفر • و إنما جعل

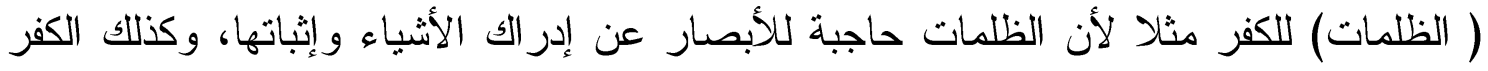

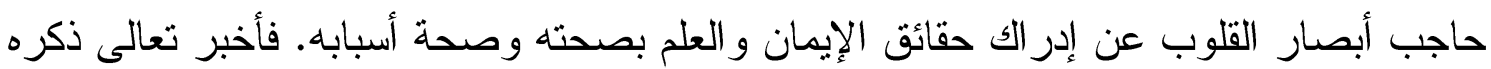

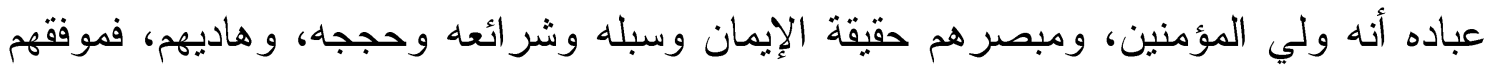

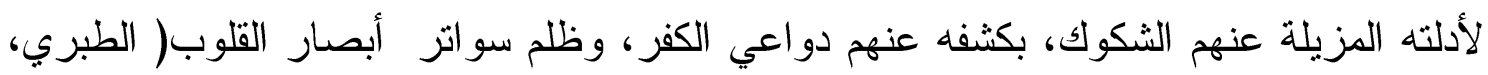

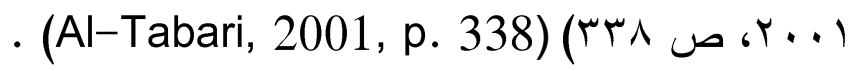

يرى الباحث أن هنالك ظلاد معان أخر للظلمة، غير المعاني المتقدمة الذكر، ومنها:

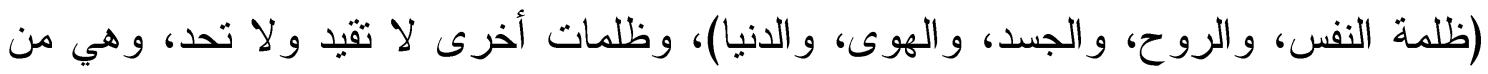

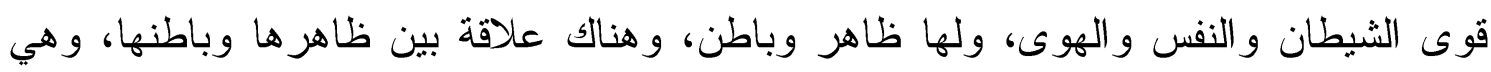

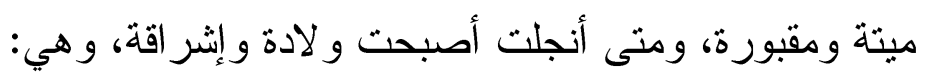

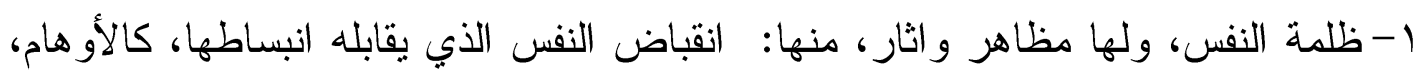

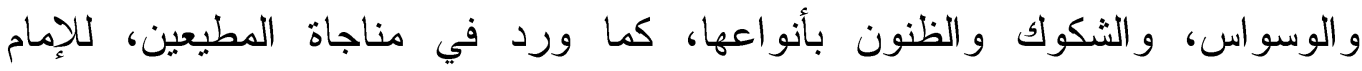

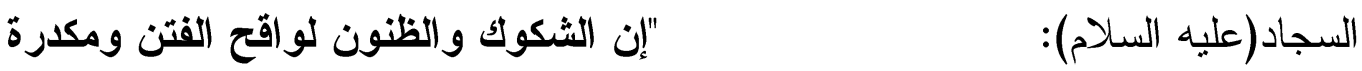

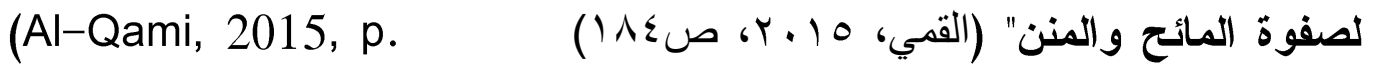

r- ظلمة الروح، وهي أثند وطاً من الاولى لعلو الهمة وسمو المبتغى، وفي هذه الحال من

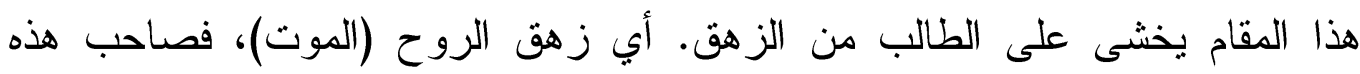

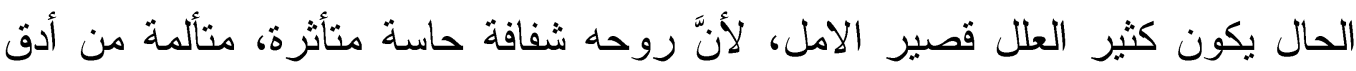

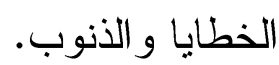

r- ظلمة الجسد، وهي معاناة الروح من كدورة الجسد، وقيوده الوثيقة، إذ ورد ذكر ظلالها

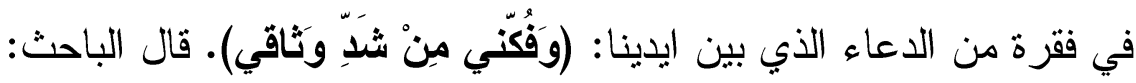

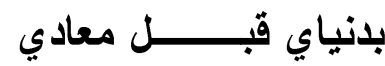

لإنقباري في عالم الأجساد

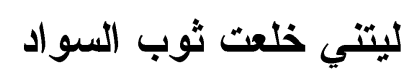

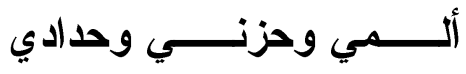

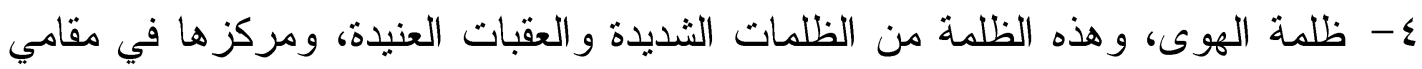

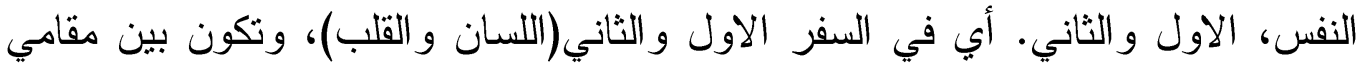


النفس و الروح، وهي ذات حدين تكاملي وتسافلي، فمتى انتصرت النفس على الروح، سلكت مسالك الرذيلة، ومتى انتصرت الروح على النفس، سلكت مسالك الفضيلة.

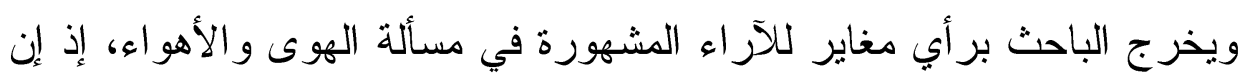

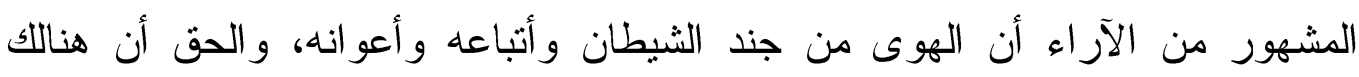

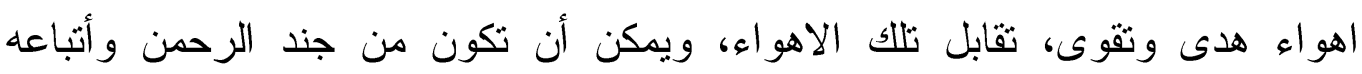

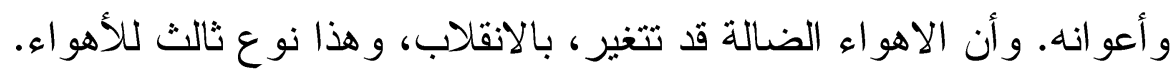

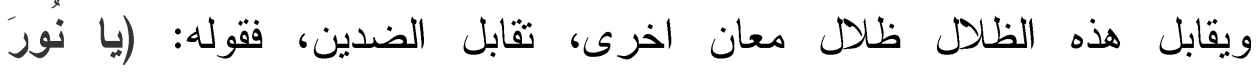

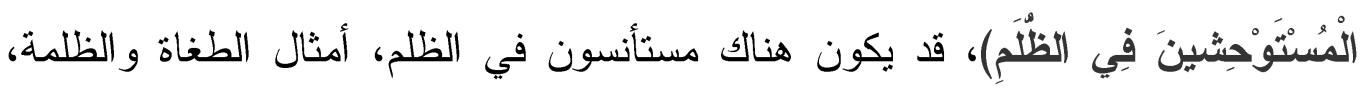

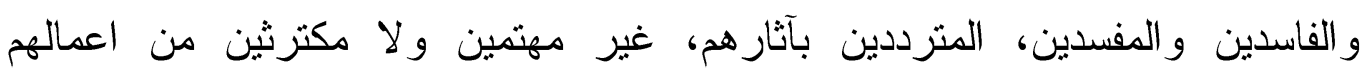

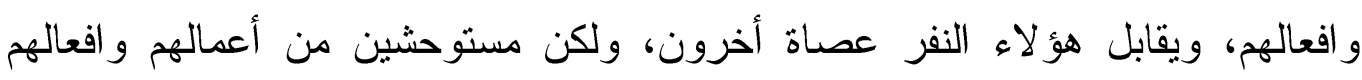

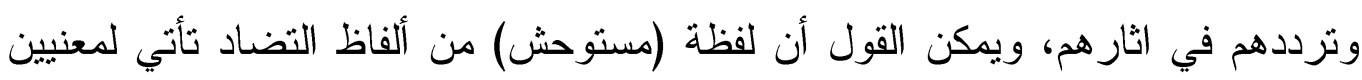
متتاقضين، كالثو هاء التي ير اد بها الحسناء.

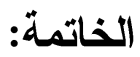

بعد أن أوشك البحث على نهايته، لابد من الإشارة إلى أبرز النتائج التي توصل اليها،

ا- إن ظلال المعنى قد تجاوزت الدلالة الحرفية إلى الدلالة المجازية، فضلاً عن أنها قد عبرت حدود التفسير والتأويل، وتجلت بمظاهر الكلمات المؤثرة، والألفاظ ذات المعاني

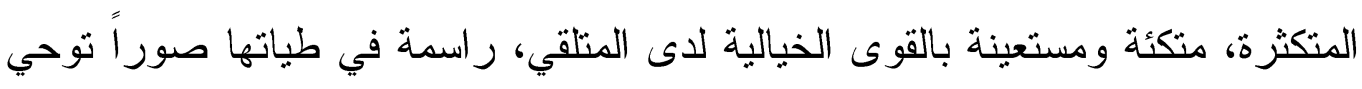
بأكثر من المعنى الظاهر. r- أسهوت علاقات ظلال المعنى في استنطاق ألفاظ النص، وكلماته ، إذ عملت على جمع أطر اف النص وربط متو اليات بعضها ببعض، مما كون حلقات اتصال بين المفاهيم.

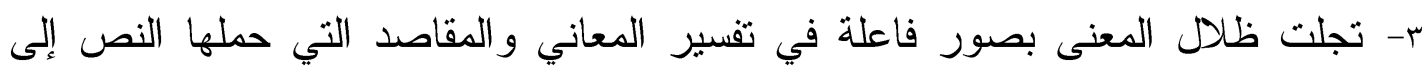

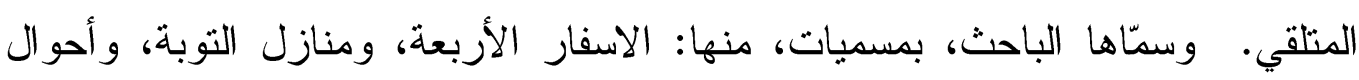

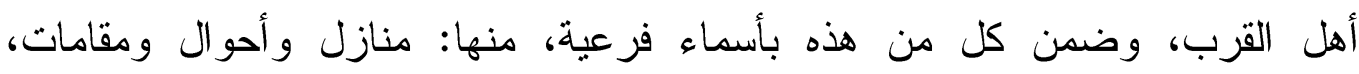

$$
\text { و وغير ها. }
$$

ء- إن للألفاظ ظلال معنى في ذاتها، و أخرى تســتوحى هـن السياق الذي ترد فيه،

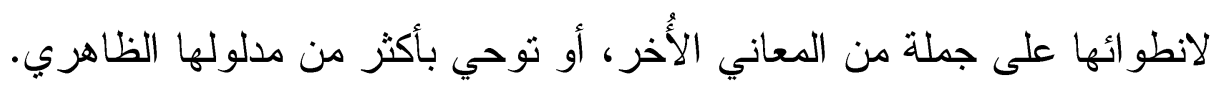


ه- الاعتر اف هو أخر منازل التوبة، وأول منازل المعرفة، وبه يلج التائب عالم الرواح، كما تلج الروح الجنين وهو كذلك بداية الحياة، فيورث في النفس صفاءً ونقاءً وطهارةً مستمرة، بعدم تدنس الانفس بمدلهمات ثياب الذنوب و المعاصي.

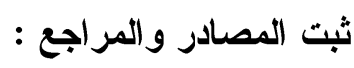
القر آن الكريم.

ابن عربي، محي الدّين (11 • rم). المعر اج، تحقيق: سعاد الحكيم، ندرة للطباعة و النشر.

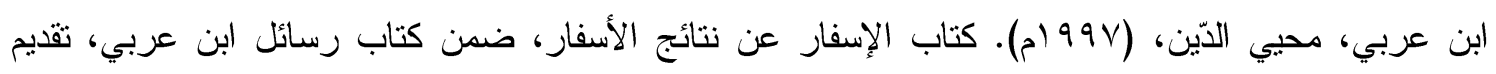

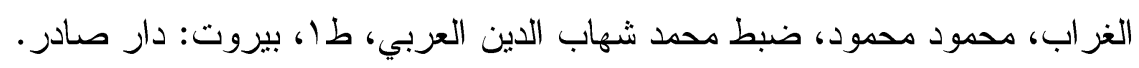

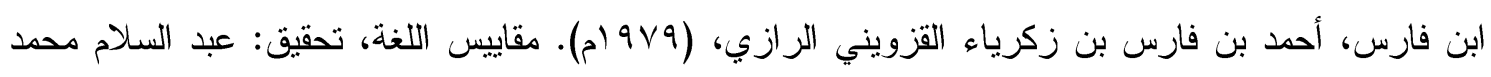
هارون، دار الفكر.

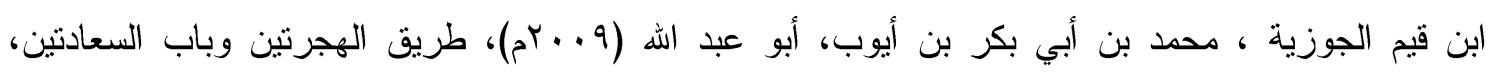

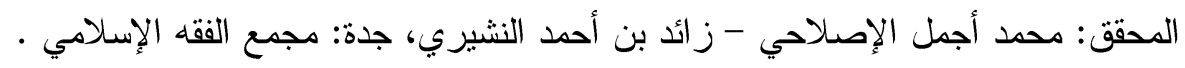

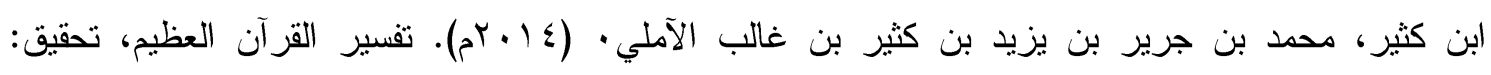

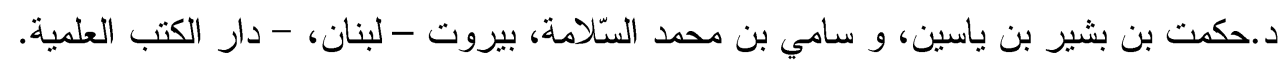

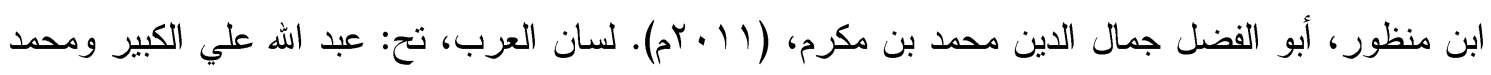

أحمد حسب الله و هاشم محمد الثاذلي، دار المعارف، القاهرة.

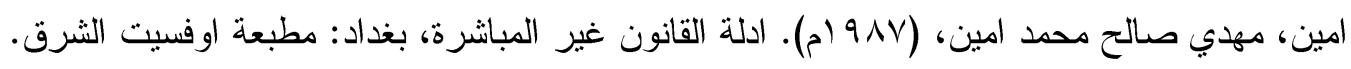

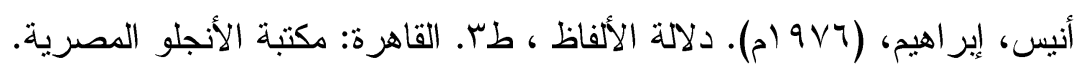

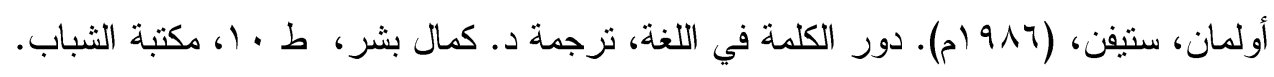

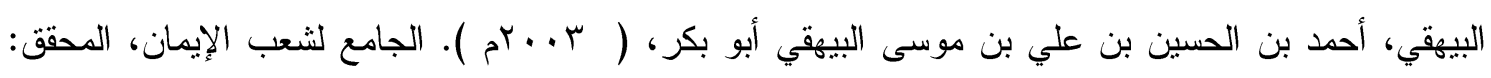

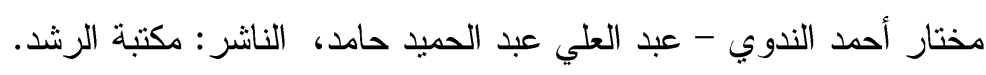

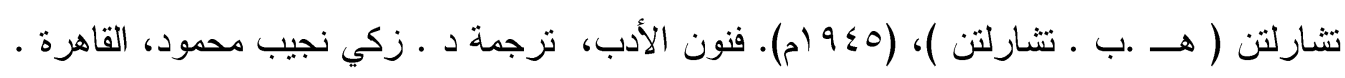

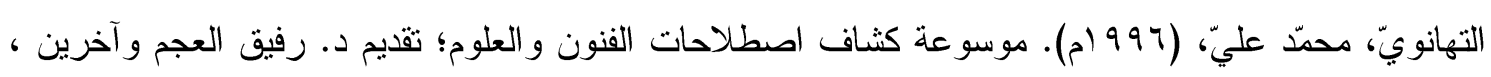
طا، بيروت: مكتبة لبنان النانشرون.

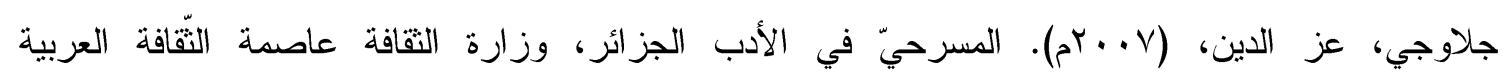

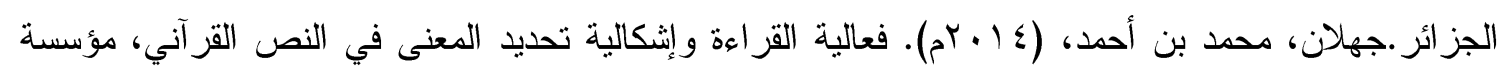
عبد الحميد شومان. الجوهرجي، محمد صالح، (911 (م). ضياء الصالحين، طب. الكويت: مكتبة الالفين.

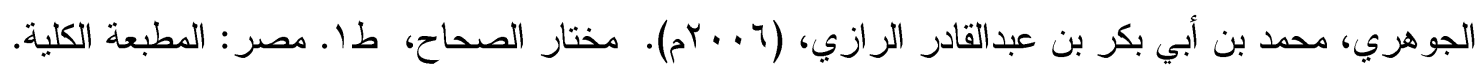

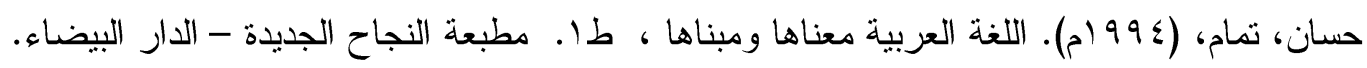

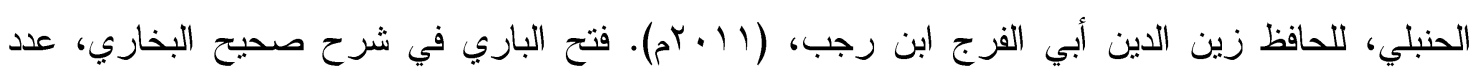

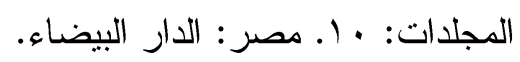


حنورة، مصري، (T +. rم). علم نفس الأدب، طلا. القاهرة: دار غريب . الزبيدي، محمد مرتضى الحسيني (9VY (م). تاج العروس من جوالهر الهر القاموس، تح: إبر اهيم التززي، مطبعة حكومة الكويت.

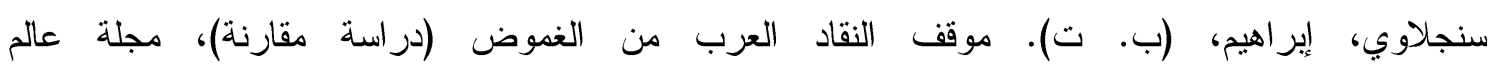

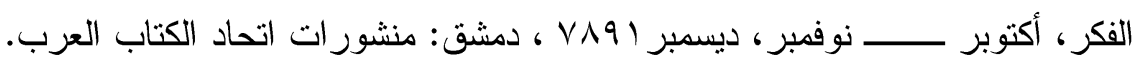
السنهوري، (r/919) المعجم الوسيط، طبعة: نادي القضاة.

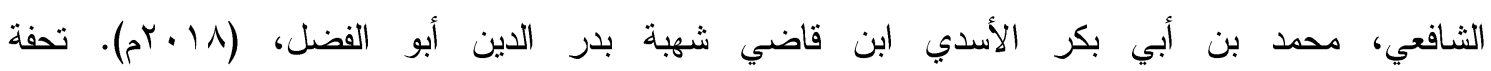

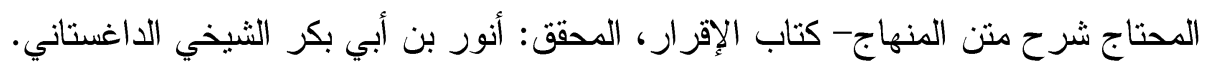

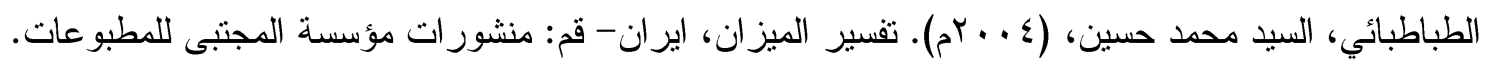

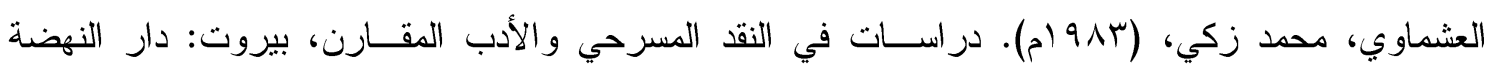
العربية. عمر، احمد مختار، (Y19 (1). علم الدلالة، الكويت: مكتبة دار العروبة.

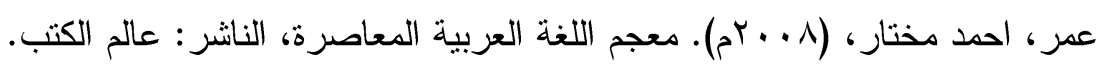

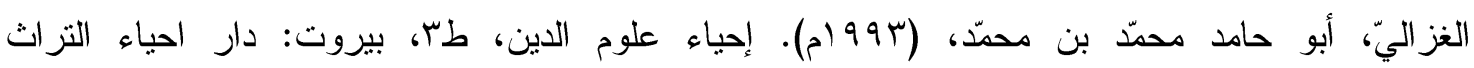
العربيّ ومؤسسة التاريخ العربيّ.

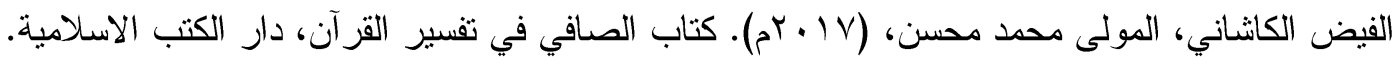
الفيومي، احمد بن محمد بن علي، (ع . .rم). المصباح المنير في قريب الثرح الكبير، بيروت: مطبعة مكتبة البيان.

القبانجي، السيد حسن، (r ( • ra). مسند الإمام علي (ع) ، تحقيق: الثيخ طاهر السلامي، المكتبة العقائدية. قطب، سيد، (به9 (م). نظرية التصوير الفني عند صلاح عبد الفتاح الخالدي، دار الفرقان للنشر و التوزيع.

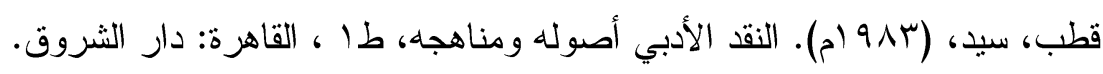

القمي، الثيخ عباس، (10 ـ بر). مفاتيح الجنان، مجمع إحياء الثقافة الإسلاميّة.

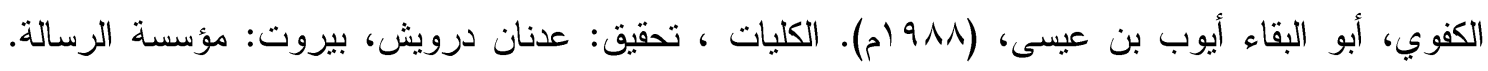

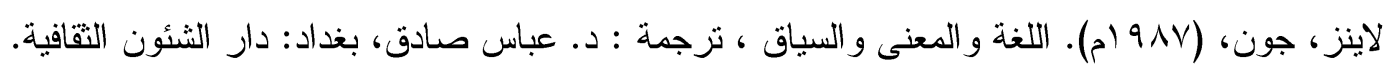

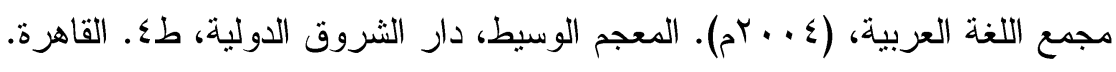

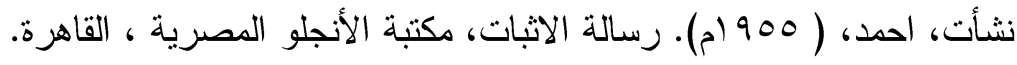

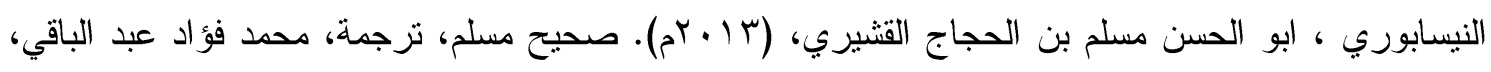
بيروت: دار احياء التزاث. 
References

The Holy Qur'an.

Amin, Mahdi Saleh Mohammed, (1987). Indirect Evidence Law, Baghdad: Offset Press, East.

Anis, Ibrahim, (1976). Semantics, i 3. Cairo: Anglo Egyptian Library. Ibn Arabi, Mohi al-Din (2011). Miraj, realization: Suad al-Hakim, a scarcity of printing and publishing

The Arabic Language Academy, (2004). Intermediate Dictionary, Dar Al Shorouk International, 4th floor. Cairo.

Al- Ashmawy, M. Z. (1983). Studies in Theater Criticism and Comparative Literature. Beirut: Arab Renaissance House.

Al-Bayhaqi, Ahmed bin Hussein bin Ali bin Musa al-Bayhaqi Abu Bakr, (2003). Mosque of the People of Faith, Detective: Mukhtar Ahmad Al-Nadawi - Abdul Ali Abdul Hamid Hamid, Publisher: Al-Rushd Library.

Al- Fayoumi, A.(2004). Al-Musbah Al-Muneer. Near Sharh al-Kabir, Beirut: AlBayan Library Press.

ibn Makram, (2011). Tongue of the Arabs, Open: Abdullah Ali Kabir and Mohammed Ahmed Hassaballah and Hashem Mohamed Shazly, Dar al-Maaref, Cairo.

Ibn Arabi, Mohiuddin, (1997). Book of the Fluorescence on the results of the travels, within the book of Ibn Arabi, presented by Mahmoud Mahmoud Al-Ghurab, seized Mohammed Shihab al-Din al-Arabi. $1^{\text {st }}$ Edition. Beirut: Dar Sader.

Ibn Faris, Ahmad ibn Faris ibn Zakaria al-Qazwini al-Razi, (1979). Language Standards, Achieved by: Abdel Salam Mohamed Haroun, Dar Al Fikr.

Al- Qabbanji, H.(2012). Musnad Imam Ali (p), investigation: Sheikh Taher Salami, doctrinal library.

Al- Qomi, Sheikh Abbas, (2015). Mafateeh Al Jinan.the Council for the Revival of Islamic Culture.

Al- Shafi'i, Muhammad ibn Abi Bakr al-Asadi, son of the judge of Shahba Badr alDin Abu al-Fadl, (2018). Masterpiece of the needy Explanation of the curriculum Book acknowledgment, the investigator: Anwar bin Abi Bakr Sheikh Dagestani.

Al- Hanbali, by Hafiz Zainuddin Abu al-Faraj Ibn Rajab, (2011). Fath al-Bari in the explanation of Sahih al-Bukhari, the number of volumes: 10. Egypt: Casablanca.

Hanoura, misri, (2006). Psychology of literature. $1^{\text {st }}$ Edition Cairo. Gharib Publishing House.

Al-Ghazali, Abu Hamed Muhammad ibn Muhammad, (1993). Revival of the Sciences of Religion, 3rd floor, Beirut: House of Revival of Arab Heritage and Foundation of Arab History.

Al-Jawharji, Mohammad Saleh, (1988). Zia righteous, i 2. Kuwait: The Library of Two Thousand.

Al-Jawhari, Mohammed bin Abi Bakr bin Abdul Qader Al-Razi, (2006). Mokhtar al-Sahah, i 1. Egypt: College Press.

Al-Kafawi, Abu al-Surah, Ayyub ibn Issa, (1988). Adnan Darwish, Beirut: Resala Foundation. 
Al-Kashan fid, Mawla Muhammad Mohsen, (2017). Safi book in the interpretation of the Koran, the House of Islamic Books.

Al-Qushayri al-Nisaburi, Abu al-Hasan Muslim bin al-Hajjaj, (2013). Sahih Muslim, translation, Mohamed Fouad Abdel Baqi, Beirut: House of revival of heritage.

Al-Sanhouri, (1983) Lexicon mediator, edition: Judges Club.

Al-Tabatabaei, Mr. Mohammed Hussein, (2004). Tafseer al-Liban, Iran - Qom: Mojtaba Publications.

Nashaat, A.(1955). Evidence Letter.Anglo Egyptian Library, Cairo. Ben Manzour, Abul Fadl Jamal al-Din Muhammad.

Charlton, (HP Charlton), (1945). Arts literature, translation d. Zaki Naguib Mahmoud, Cairo.

Galawji, Ezze al-dine, (2007). Drama in Literature Algeria, Ministry of Culture Capital of Arab Culture Algeria.

Al-Jawziyyah, Ibn Qayyim, Muhammad Ibn Abi Bakr Ibn Ayyub, Abu Abdullah (2009), the way of migrations and Bab al-Sa'adein, the investigator: Mohammed Ajmal reformist - plus bin Ahmed Nashiri, Jeddah: Islamic Fiqh Academy.

Ibn Kabir, Mohammed bin Jarir bin Yazid bin Ghalir bin Ghaleb al-Amlai0 (2014). Interpretation of the Great Qur'an, Investigation: Dr. Hikmat bin Bashir bin Yasin, Sami bin Mohammed Al-Salama, Beirut, Lebanon, Dar al-Scientific Books.

Jahlan, Mohammed bin Ahmed, (2014). The effectiveness of reading and the problem of determining the meaning in the Quranic text, Abdul Hameed Shoman Foundation.

Lines, John, (1987). Language, Meaning and Context Abbas Sadiq, Baghdad: House of Cultural Affairs.

Qutb, Sayyid, (1983). Literary Criticism: Its Origins and Methods, 1st Floor, Cairo: Dar El Shorouk.

Qutb, Sayyid, (1983). Theory of Artistic Photography by Salah Abdel Fattah AlKhalidi, Dar Al-Furqan for Publishing and Distribution.

Ullman, Stephen, (1986). The role of the word in the language, translation d. Kamal Beshr, i 10, Youth Library. Singlawi, Abraham, PT. The position of Arab critics on ambiguity (comparative study), Journal of the World of Thought, October-November, December 7891, Damascus: Publications of the Arab Writers Union.

Hassan, Tamam, (1994). Arabic language meaning and its building, i 1. New Success Printing Press - Casablanca.

Thawandi, Muhammad Ali, (1996). Encyclopedia Scout conventions of arts and sciences; Rafiq al-Ajam et al, 1st floor, Beirut: Library of Lebanon Publishers.

Al-Zubaidi, Mohammed Mortada Al-Husseini (1972). Crown Bride of Jewels Dictionary, under: Ibrahim Tarazi, Government of Kuwait Press. 